\title{
My science class and expected career choices - a structural equation model of determinants involving Abu Dhabi high school students
}

\author{
Masood Badri ${ }^{1 *}$, Ali Alnuaimi ${ }^{2}$, Jihad Mohaidat ${ }^{3}$, Asma Al Rashedi ${ }^{1}$, Guang Yang ${ }^{1}$ and Karima Al Mazroui ${ }^{4}$
}

\begin{abstract}
Background: This study is about Abu Dhabi high school students' interest in science in different contexts. The survey was conducted in connection with the international project, the Relevance of Science Education (ROSE). The sample consists of 5650 students in public and private schools. A structural equation model (SEM) is developed to capture the links between the various constructs. The model hypothesize that students' future job expectations have several significant determinants or constructs related to their interest in science, out-of-school experiences, attitude toward science, opinion about science class, and opinion about environmental challenges. Exploratory factor analysis of each of the original ROSE dimensions provided the factors and constructs for the SEM. Summated scores of factors are used for the SEM analysis.
\end{abstract}

Results: Constructs with the highest total effect are "my science class," "my attitude toward science," and "my interest in science." Both "my out-of-school experiences" and "my opinion of environmental challenges" have low direct effects. In this study, descriptive statistics of items are presented, and the implications for curriculum development, teacher professional development programs, and other education strategies in Abu Dhabi are discussed.

Conclusions: The study resulted in a comprehensive framework and model of factors and determinants that demonstrate an overall relationship to better understand what might trigger students to think about their expected future careers. Results show that just making science lessons interesting or informing students about social significance of science, technology, engineering, and mathematics (STEM) is not enough to sway young people toward STEM careers. The current study goes one step further in an attempt to link the various dimensions in a unified SEM to better understand the effects of the various elements on each other.

Keywords: Future job, Interest in science, Out-of-school experiences, ROSE, STEM, Science education, Abu Dhabi

\section{Background}

A number of research studies conducted recently reported a decline in student engagement with science, technology, engineering, and mathematics (STEM) and subsequent choices to pursue STEM-related careers (Calabrese Barton et al. 2008; Bottiaa et al. 2015; American Institute of Physics 2014; Roberts 2002; Stagg et al. 2003). Many countries over the world face the task of recruiting

\footnotetext{
* Correspondence: masood.badri@adec.ac.ae

'Research \& Planning, Abu Dhabi Education Council, Abu Dhabi, United Arab Emirates

Full list of author information is available at the end of the article
}

more individuals into STEM industries (Hill et al. 2010). Students' interests, attitudes, self-efficacy beliefs, and images of science and scientists interact (Dimopoulos and Smyrnaiou 2005; Schreiner and Sjøberg 2004) and consequently affect their achievement (Jones et al. 2000; Britner and Pajares 2006; Siegel and Ranney 2003) as well as their study and career choices and personal and social lives (Cleaves 2005; Britner 2008; Schibeci and Lee 2003).

Numerous research pointed out that the science class and what goes on there and how it is presented play a significant role in building students' interest toward science (Samara 2015; Iqbal et al. 2015; Anderson 2006; 
Britner 2008). Two factors that come up in literature often are the class teacher and science curriculum (Yan et al. 2015; Christensen et al. 2014). Several sources have identified the quality of the educational experience provided by the teacher in class as a key factor determining engagement (Osborne et al., 2003; Bennett and Hogarth 2005). Many science teachers are required to teach sciences outside their own specialism (Murray and Reiss 2005). Research emphasized the importance of good specialists and enthusiastic teachers highlighted in an earlier research by Osborne and Collins (2001). The science curriculum was generally thought to be content heavy with too much repetition (Osborne and Collins $2000,2001)$ as well as including too much written work (Owen et al. 2008), factors that many young people were said to find dampening. There was much evidence within the literature of the preference of young people for more practical, hands-on, and interactive activities and the potential of this type of activity for encouraging engagement with science education (Osborne and Collins 2000; Cleaves 2005; Murray and Reiss 2005; Owen et al. 2008).

Another factor influencing student engagement in science education was identified as future career directions or ambitions (Osborne and Collins 2000; Cleaves 2005; Jenkins and Nelson 2005). Bennett (2003) found "considerable" evidence that ideas of future career directions (including science careers) begin to take shape in the early years of secondary school.

The Abu Dhabi Education Council (ADEC) has emphasized in its reform agenda that science education should contribute to the development in young people of positive attitudes toward learning science. As a result, encouraging students to choose science-related future job careers has important implications for not only the continuity of scientific endeavors but also the scientific literacy of future generations. Consequently, the development of positive attitudes toward science, scientists, and learning science, which has always been a constituent of science education, is increasingly becoming a subject of concern. Policy leaders in ADEC are creating partnerships with large international businesses and organizations to recruit more teachers in STEM areas with the goal of engaging and advancing more students, expanding career opportunities for students, and creating future STEM innovations.

Using the Abu Dhabi Relevance of Science Education (ROSE) data, the current research will try to construct and test a general model or framework for the determinants of students' future job ambitions using other latent constructs related to interest in science. These constructs are related to out-of-school experiences, attitude toward science, opinion about science class, and opinion about environmental challenges. The objective is to provide numerical estimates for each of the parameters in the model to indicate the significant strength of the relationships. Thus, in addition to testing the overall framework, the study will try to diagnose which observed variables are good indicators of the latent variables in the model.

\section{Literature review}

One of the aims of learning science at school is to prepare individuals to take up science-related occupations or jobs (Aikenhead 2005). In view of this, the important goal of relevant science education is to recognize the perceived need to prepare and equip learners for future occupation. Some studies revealed that some factors are taken into consideration by students when decisions on the career choice or path are made (Sadler et al. 2012; Correl 2004; Lewis and Collins 2001). Such factors are likely to be the different hopes and priorities students hold for their future, which might be important for the choice of a future occupation or job. Besides the nature of the science curriculum, the knowledge that teachers have of their learners is considered an important factor for learning (Ogunkola 2011). The main objective of the literature review section is to summarize the importance of the items that were used in the original ROSE survey.

\section{My future career}

Wang and Staver (2001) studied the relationships between factors in science education and student career aspirations. Results showed that career aspiration is more influenced by the value of science training than ambition. Among factors of educational productivity, educational outcome had the strongest link with career aspiration. The influences and motivations on which students base their choice of career were studied by Kniveton (2004). Overall motivation toward work was found primarily to involve money and liking the job. Most noticeably, the students considered the status derived from possessions rather than employment. Meanwhile, VanLeuvan (2004) identified variables such as locus of control, self-concept, socio-economic status, parental involvement, parental expectation, math selfefficacy, and reading self-efficacy as mostly influencing science- and engineering-related career aspirations.

Packard and Nguyen (2003) stressed that discussions of how careers impact communities need to be an explicit focus of career programs so that careers are not eliminated due to lack of information or stereotypical perceptions. Research showed that students regard topics related to human biology (health, diet, and fitness; diseases and cures), plants and animals, light and sound, and space and astronomy as particularly interesting; at the same time, girls' interest in these areas is significantly higher than boys' (Christidou 2006; Osborne and Collins 2001). 
Reid (2003) stressed the importance of the differentiation of students' sex roles in societies as well as their representation, interest, and performance in some science subjects. Some studies revealed that girls typically select science-related careers that offer opportunity to help people, animals, plants, and the earth (Jones et al. 2000). Some ROSE studies indicated that becoming "the boss" at their jobs, helping other people, coming up with new ideas, and earning lots of money were priorities as future careers. In other words, managerial position appeared crucial for a good income in addition to be able to help people and come up with new ideas. A study conducted with Finnish students indicated that a good income was high on the job priority list for both genders (Lavonen, Byman, et al. 2008a, b). Similarly, good income seemed to be the general desire of the majority of the youth. Clewell and Campbell (2002) observed that some students are deterred from participating in STEM careers as a result of low salaries and inequitable distribution of career rewards.

\section{Students' interest in science}

There is an extensive literature on students' interests and enrollments in science (Gardner 1975; Ormerod and Duckworth 1975; Osborne et al. 2003; Gardner and Tamir 1989; Osborne and Collins 2001; Colley et al. 2003). In most developed countries, many young people appear to lose interest in science and technology in schools and further studies (Black and Atkin 1996).

Ormerod and Duckworth (1975) pointed out that interest in science appears to be aroused at an earlier age than in other curriculum areas, suggesting that a primary science experience might be important for future students' long-term interest in the subject. Craig and Ayres (1988) stated that the level of interest among some students, which at the primary school had been high, appeared to have dropped considerably so that those students who had the greatest primary science experience now gave the lowest response to questions about interest in future school science topics. In Germany, Haussler (1987) confirmed the general trend that the overall interest in physics decreases as the students grow older. As students advance from primary to secondary education, students rapidly lose their interest in science and cease seeing it as a viable option for their future or associating it with their success aspirations (Bowtell 1996). Trumper (2006b) pointed out that the most influential factor in students' interest in science is their poor opinions about science classes in junior high school.

Several contributing factors have been advanced for students' declining interest in science during school. One such factor was the apparent lack of relevance of the school curriculum to teenagers' curiosity and interest (Millar and Osborne 1998).
Several studies revealed that relatively negative attitudes of students are usually associated with more traditional approaches to science instructions (Olasimbo and Rotimi 2012; Lord 1997). Some pointed out that students' perceptions of science classrooms as constructivists are correlated positively to student interest (Aldridge et al. 2000). A number of studies in science education showed that boys have greater interest in science than girls (Osborne and Collins 2001; Colley et al. 2003).

\section{Students' attitude toward science}

Bennett (2003) asserted that a substantial proportion of the literature focuses on the problems and difficulties associated with research into attitudes to science. He used the term "dispositions toward" when identifying different attitudinal constructs for attitudes to science. She also used the terms "attitudinal construct" and "attitudinal strands." Bricheno et al. (2000) used the term "groups of attitudes."

The increased focus on attitudes can be seen, for example, in the Organization for Economic Cooperation and Development's (OECD) Program for International Student Assessment (PISA) in three domains: reading, mathematics, and science. In the lifespan of the PISA research, discussions about science education have been wide ranging, and the purposes of science education have also been redefined and broadened (OECD 2006). The willingness to engage in science-related issues is important not only with regard to the choice of educational pathways and careers but also with regard to the role of being a reflective citizen.

Research has concentrated on identifying aspects of affective strands of attitudes and the effects of affective attitudes on behavior and cognition (Bricheno et al. 2000). In their study, seven groups of attitudes were identified and measured: (1) attitudes toward the social implications of science; (2) toward the normality of scientists; (3) toward scientific inquiry, which are needed to be scientific; (4) toward the enjoyment of science lessons; (5) toward science as a leisure interest; and (6) toward a career in science. Osborne et al. (2003) pointed out that attitudes toward science consist of a large number of subconstructs, all of which contribute in varying proportions. The constructs include social- and psychological-related constructs. They have an interesting resemblance to many of the processes of student engagement drawn from the research literature by the PISA researchers. This can, for example, be seen by the emphasis on self-related cognitions such as self-esteem with regard to science and emotional factors such as anxiety toward science and fear of failure on a course.

Keeves and Kotte's (1992) examination of students from ten different countries found that males consistently held more favorable attitudes toward science than 
females, even though females were more interested in school and school learning in general. Male students also found science easy rather than difficult to learn, whereas female students were less positive about the ease of learning science. It should be noted, however, that a recent study on Arabic cultures (Said et al. 2016) did not find significant differences on gender in attitudes toward science among grades 3 through 12 Arab students in Qatar.

\section{Perception of school science}

Students' low interest in science and their relatively negative attitudes are at least partially attributed to the way relevant disciplines are taught at school. Science curricula, school textbooks, and teachers and their teaching practices are crucial factors considered to negatively affect students' attitudes toward an interest in science, since they tend to emphasize its academic, strongly intellectual, and abstract character and to present it in a decontextualized manner distanced from everyday life (Semela 2010). Sjøberg (2002a) noted that school science may be perceived as playing a crucial role for accomplishing students' beliefs. One may ascribe this as one of the reasons that students tend to believe in the benefit of learning school science. It could also be interpreted that the science that students relate to at school inspires, excites, and meets their aspirations. Students are likely to experience some aspects of school science that are perceived to be mathematical and hence difficult (Sjøberg 2002b). Students' perceptions of science are related to their views of scientific knowledge and practice from science classes and to their attitudes toward science (Oversby 2005; Schibeci and Lee 2003).

The classroom environment and science teaching practices employed are considered particularly important in shaping students' multiple and fluid identities (Buck et al. 2009; Tan and Calabrese Barton 2008a, b). The image cultivated to students through science teaching at school is that science consists of objective and value-free knowledge (Kelly 2000; Osborne et al. 2003; Sjøberg 2002a, b, c). Thus, traditional science instruction at school fails to introduce students to the real world of scientific environments or the professionals who work there (Scherz and Oren 2006).

Some studies reported that students state that science as a school subject is irrelevant and therefore not useful in everyday life (Siegel and Ranney 2003). In their view, there is a considerable mismatch between science-insociety and science-in-school. School science is unattractive since it does not involve topics of interest, it does not provide students with opportunities for creative expression, and it is fairly alienated from society (Henriksen and Mishra 2013; Buck et al. 2009; Kelly 2000; Osborne and Collins, 2001; Osborne et al. 2003; Ryder 2002; Sjøberg 2002a, b, c; Christidou 2006).
School science fails to expose state-of-the-art research as presented in the public field (e.g., by the mass media) and as perceived by the general public (Dimopoulos and Smyrnaiou 2005). Moreover, school science is usually fragmented in different, strictly isolated disciplines, and/ or presented in contexts of limited interest for students, thus failing to provide students with a coherent picture (Siegel and Ranney 2003).

At school, science teachers play an especially crucial role in the formation and reorganization of students' conceptions and attitudes toward science and scientists (Turkmen 2008). Teachers' inadequate understanding of the nature of science may pose difficulties in introducing coherent and compelling teaching practices addressing their students' interests and experiences and perpetuate to implement traditional, teacher-centered instruction (Bianchini et al. 2003). Teachers with a positive view toward science tend to inspire analogous positive stances in their students (Koch 1990). On the other hand, many teachers have been found to adopt stereotypic images of scientists identical to those of students (Hatzinikita 2007). These teachers are expected to have a negative impact on the ways their students conceive of science and scientists (Quita 2003). Such teachers might exert a negative effect on the students' likelihood of selecting and pursuing school science courses and, accordingly, of opting for a future career related to science (Quita 2003).

\section{My out-of-school experiences}

There is significant effect of out-of-school experiences on the development of interest in science (Sjøberg 2000a, b; Christidou 2006). Biology and physics relatable experiences contribute equally to interest in science, contrary to the belief that, generally, life-oriented topics are preferred by students (Baram-Tsabari and Yarden 2005). Some students do not have a well-formed appreciation of the nature of science and the work that scientists undertake (Jones and Kirk 1990). Organizing experiential outdoor learning environments would be important for students in order to evoke an interest in science-related phenomena (Cavas et al. 2009; Bogner and Wiseman 2004). Students might learn science with better understanding when there is a closer connection among classroom learning, the environment, and the practical experiences of the students.

Sjøberg (2002a) is of the view that there is a general acceptance that all teaching should "build on" the interest and experience of the child. Teaching content must have some relevance, and it must fit into the personal curiosity or societal context of the child. Studies also indicated that in most countries, there is a considerable gap between what is learned in the classroom and the real-life context of the student (Chang et al. 2009; Muskin 1997). Criticism continues to be leveled against 
traditional science for its lack of relevance for the everyday world (Osborne and Collins 2000). Out-of-school experiences require social participation that offers students social support, whereas school-based experiences do not (Melnick 1991). Allowing social interaction creates a real interest in the topic and a desire to learn besides cognitive gains (Koosimile 2004). Uitto et al. (2006) reported that out-of-school nature experiences are the most important factor that determined interest in biology, and as girls gained more nature experiences, they showed more interest in biology.

Some studies showed that boys and girls appeared to have similar outside school activities in the developing countries (Sjøberg 2000b; Sjøberg 2002a). However, boys tend to be more adventurous than girls and might have skills and experiences from those adventures, which are relevant for science and technology education. Some gender differences in interest in the above activities were reported in other studies that made use of the ROSE questionnaire in their studies (Jones et al. 2000). Some studies showed that boys continue to have more extracurricular experiences that are related to physical sciences than girls, whereas girls had more experiences than boys in biology (Sjøberg 2002a; Sjøberg 2000b). Hyde and Jaffee (1998) and Jones et al. (2000) implied that when girls are exposed to more frequent and early out-of-school time experiences, their achievement and interest in physical sciences might be enhanced as they continue their education. Nevertheless, Clewell and Campbell (2002) reported that the overall impact of the difference between these outside of school time science experiences for boys and girls on their participation in science is still not fully understood. According to Schwedes (2005), it seems that boys' activities appear more often to have relevance for science learning since boys are usually encouraged by parents in using tools such as hammer, saw, file, or electric drill, whereas girls are warned not to use such tools in order not to hurt themselves. Uitto et al. (2006) found that on average, girls had more naturecentric attitudes toward environmental values and positive attitudes toward environmental responsibility than boys, who had more anthropocentric attitudes. Boys had more experience in mechanical activities, whereas girls had more nature-related activities (Sjøberg 2000a, b). In India, too, out-of-school science experiences are more for boys than girls (Gafoor and Smitha 2012). Boys have more experience in tinkering activities associated with physics, and girls are more involved in domestic and nature study activities. Boys engage more in manual work and using computers and are more interested in the social dimensions and threatening aspects of science and technology (Christidou 2006).

Tunnicliffe and Reiss (2000) found that the home was a more important source of knowledge in plant classification than school. Students' interests, or non-interests, in different contexts of biology may thus be an expression of individual longer lasting interest (Krapp 2005) in informal out-of-school nature-related contexts. In the study by Uitto et al. (2006), experience in using information technology, such as playing computer games and emailing, did not relate to an interest in varying contexts of biology. Even if computer-aided learning has been found useful in learning biology (Kroß, 1998), compelling free-time hobbies centered on information technology may estrange students from real-life experiences (Gafoor and Smitha 2012).

\section{Student views about environmental challenges}

The positive attitudes of students toward environmental challenge issues cut across all countries but of varying degrees (Szagun and Pavlov 1995), and the environmental matters appear to be one of the most pressing topical socio-scientific issues of the global world. The fact is that many students from different cultures continue to show concerns for the future of the globe (Schreiner and Sjøberg 2004).

Szagun and Pavlov (1995) noted that the environmental matters are a global concern for young learners. This is seen in light of the fact that many students from different cultures continue to show optimisms about the future of the globe and believe in their abilities to help in solving environmental problems through various actions (Schreiner and Sjøberg 2004).

It is essential for research in environmental education to identify students' conceptions and understanding about the environment (Payne 1998). Science education has a key role in preparing young people to cope with the emergence of environmental challenges. When students are well exposed to school science, they are likely to make informed decisions and actions on environmental challenges (NRC 1996). Huang and Yore (2003) suggested that prior knowledge as well as values, beliefs, attitudes, concerns, and emotional dispositions of learners might influence their understanding about and capabilities to act toward the environment. Teaching needs to be based on students' knowledge, attitudes, and conceptions of the environmental protection issues (Schreiner and Sjøberg 2004).

Although the ROSE questionnaire is not specifically designed to measure environmental attitudes, this questionnaire has the rare advantage of gathering information about students' opinions of school science and science-related issues. In general, including environmental issues, and at the same time, several other factors that have a bearing on their attitudes to science and technology and their motivation to learn science and technology (Jenkins 2006; Jenkins and Pell 2006; Hebel et al. 2014). It should also be added that only after understanding the relationships between the attitudes that students have toward the environment and the factors that influence these attitudes will we be able to propose 
a way of teaching that could have a chance of improving the public's attitudes toward nature. As a result, it is suggested here that the attention paid to the mutual relationship with science education is primarily driven by such environmental issues.

\section{Studies related to direction of the associations among STEM factors}

Several STEM-related studies using correlation or structural equations addressed the direction of the relationships between the constructs. However, the studies were limited to certain aspects and variables. Many relation-type studies related to STEM and future jobs were focused on biographic, socio-economic features. Wang (2013) introduced a multiple-group structural equation modeling analyses to explore the relationships among high school exposure to STEM courses, math preparation, math self-efficacy beliefs, interest in pursuing STEM upon entry into postsecondary education, and entrance into STEM fields of study. The study revealed direct link between entrance into STEM field as dependent variable and readiness in Math and Science, achievement in Math, and attitude toward Math. Kim and Song (2010) used structural equation model (SEM) to establish direct link between STEM-related conceptual understanding, intrinsic/extrinsic attitude, and school achievement. The extrinsic attitude included future opportunities. The study by Miller and Kimmel (2010) used 21 variables to predict employment in STEM or medicine (STEMM). A SEM found that mathematics is a primary gateway to a STEMM career, along with some family factors of a young adult entering a STEMM profession. Miller and Solberg (2012) outlined the rationale for the separate analysis of the pathways to STEM. Both Kier et al. (2016) and Tyler-Wood et al. (2010) developed a STEM-focused survey to identify students with academic and career potential in STEM areas. The surveys assumed that the attitude of students in STEM and science class variables have direct effect on entering STEM-related careers. Many studies noted that attending high-quality STEM afterschool (or out-of-sch00l) programs yielded STEM-specific benefits of improved attitudes toward STEM fields and careers; increased STEM knowledge and skills; and higher likelihood of graduation and pursuing a STEM career (U.S. Department of Commerce 2011; Hossain and Robinson 2012). The direct impact of out-of-school experiences on future plans is portrayed clearly in many studies (Hosler and Stage 1992). Other studies addressed biographic, socioeconomic factors and student achievement in Math and Science as main determinants (Manski and Wise 1983; Tuttle 1981; Crisp et al. 2009). Using confirmatory factor analysis, Unlu et al. (2016) adopted the STEM career interest survey to assess middle school student's interest in science. However, the study did not go further to explore linkage possibilities with other determinants.

\section{Methods}

Theoretical framework of the study and model framework Science education can be contextualized and linked to the world life experiences of learners. The new experiences are used by the learner to construct a new meaning. Strike and Posner (1992) noted that constructivist-based research suggests that informal science experiences lay the critical foundations for deep conceptual understanding (Jones et al. 2000). Learners' understanding of school science is conditioned by their present common sense experiences to a large extent. This understanding in turn is shaped by their prior encounters with various natural phenomena, even though their interpretations of such encounters may or may not be scientifically valid (Ebenezer and Connor 1998). As a result, it is important that the curriculum should be shaped to reflect students' learning experiences in the affective domain (Driver et al. 1996).

A constructivist teacher plays a key role at the interface between curriculum and student to bring the two together in a way that is meaningful for the learner. Teachers with a constructivist viewpoint can influence the understanding of their students and plan mediating events that assist students in moving from the current understanding, which is not scientifically based, to a more scientifically accepted understanding (Driver et al. 1996). Learning involves both the cognitive and affective domains. The learner can only be motivated to engage in meaning making in science only if it is of interest and value to the learner. The nature of interest and value that the learner has toward science leads to the development of attitudes toward the discipline. The learner is further motivated to engage in science learning only if the subject matter is relevant to the learner's daily activities.

The ROSE framework proposes that there are six constructs that exert effects on each other. The current study proposes an exogenous variable that denotes students' expectation of future job or career prospects (Anderson et al. 2006; Christidou 2006). It also proposes the existence of five other domains that are reflected in students' interest in science, his/her attitude to science class, his/her out-ofschool experiences, his/her attitude toward science, and his/her opinion about environmental challenges. Views of the future are inevitably influenced by both the personal background of the individual and contemporary societal events and developments (Schreiner and Sjøberg 2004). By knowing the images and visions that young people hold of the future, one can better understand their motivation, choice, and actions.

The ROSE framework provides important parameters and assumptions:

- An underlying assumption in the current research is that many young people, although they do not plan to be scientists or have a scientific career, 
find various aspects of science interesting (Sarjou et al. 2012).

- The idea about these questions is to get empirical evidence on what sort of issues students are interested in learning about and to explore how these vary between groups and search for patterns in the answers (Creagh and Parlevliet 2014). This question may provide an insight into how different topics may or may not appeal to different groups of learners (Bottiaa et al. 2015). This information can give an insight into how science curricula may be constructed to meet the perceived needs or interests of different groups of students.

- It is important to tap different aspects of students' relationship to the environmental challenges. We need to focus equally on students' alternative conceptions of science content as well as their attitudes, priorities, and decision-making regarding science learning and environmental issues. Such information might enhance and develop knowledge and awareness of what challenges we are facing in our effort to make students equipped to meet the environmental challenges (Bottiaa et al. 2015).

- The questions about "my science class" provide information about different aspects of the students' perception of their science classes, including their motivation for science at school, their self-confidence in their own abilities in science at school, what they get out of science at school, and their perceptions of the necessity of science education (Schibeci and Lee 2003). This is because some aspects such as self-confidence, attitudes, interests, beliefs, and motivation are key factors associated with learning a subject (Britner 2008). The responses provide an opportunity to describe what students in Abu Dhabi and in different countries actually think they have learned from their science classes.

- The questions regarding "my opinions about science and technology" probe into students' perception about the role and function of science and technology in society and their expectations of science and technology (Ceci et al. 2014).

- These questions about "my out-of-school experiences" provide information about students' out-of-school experiences or activities that have a bearing on their interests in science and technology and school science (Christidou 2006). These may provide important experiences for the learning of science at school. Responses to these questions will give teachers, curriculum makers, and textbook writers a description of what kind of science- and technology-related experiences children bring to school and how these vary between girls and boys, urban and rural, and among diverse cultures (Uitto et al. 2006).
The current study is an investigation into Abu Dhabi students' attitudes, experiences, interests, priorities, expectations, and images that relate to science learning. The ROSE focuses on a variety of factors such as students' interests in learning science and technology topics in different contexts. The ROSE model framework consists of several constructs. This paper attempts to map the research literature relevant to students' voices, their science-related interests, attitudes and images of science, expected careers, and their out-of-school experiences in order to highlight critical research outcomes and implications for resolving adjacent issues.

Despite the comprehensiveness of the ROSE project in its content of variables, the project did not go further to explore the relationships between the various dimensions (or constructs).

The current study introduces a SEM to demonstrate that a complex combination of factors related to STEM education contributes to each individual's decisions leading to the future job expected. The structural equation introduced in this study demonstrated that the pathways to a STEM career are long and complex. SEM is employed to test a comprehensive model on the effect of these variables on the science-related career choices of students. The five factors employed in this study are considered as critical factors influencing the career choice of students. Implications for science education and research will also be formulated.

In our study, the relationships in the SEM could be better explained, and alternatives need to be examined/ compared. The general SEM (Fig. 1a) assumes that all five constructs (my interest in science, environmental challenges, my science class, my attitude toward science, and my out-of-school experiences) have direct influences on (my future job expected). The second model (Fig. 1b) assumes some relationships between the five constructs too. Since some of the research literatures provided some inconsistent results, it would be interesting to see if some of the directions are reversed. The third model (Fig. 1c) reverses some of the directions (my science and attitude toward science) and (out-of-school interests and attitude toward science). Testing these models will provide the true effect directions.

\section{The survey instrument and distribution}

The ROSE survey was conducted in Abu Dhabi in 2015. The ROSE questionnaire contains about 250 items, including 108 statements on students' interests in science education, and is divided into three sections. On a fourpoint scale (from not interested to very interested) for each statement, students were asked to indicate their response by ticking the appropriate box. The general question for each of the statements had the heading of "What I want to learn about? How interested are you in 
a

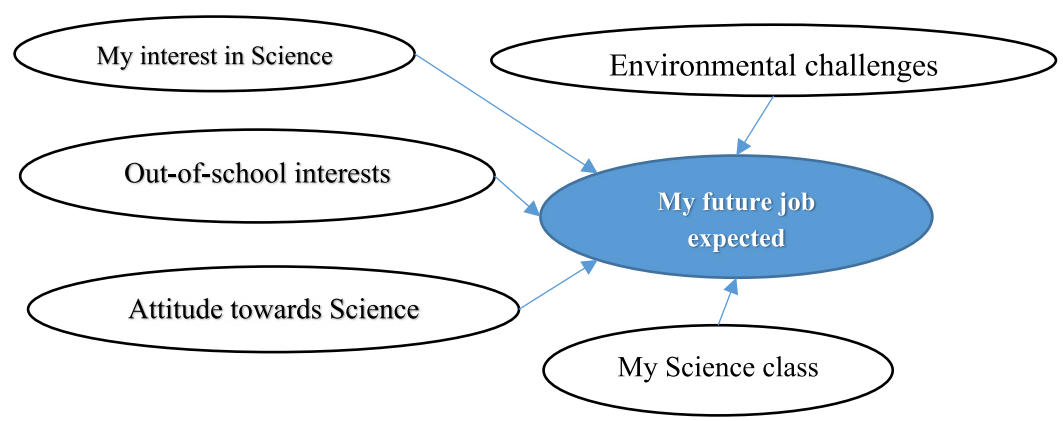

b
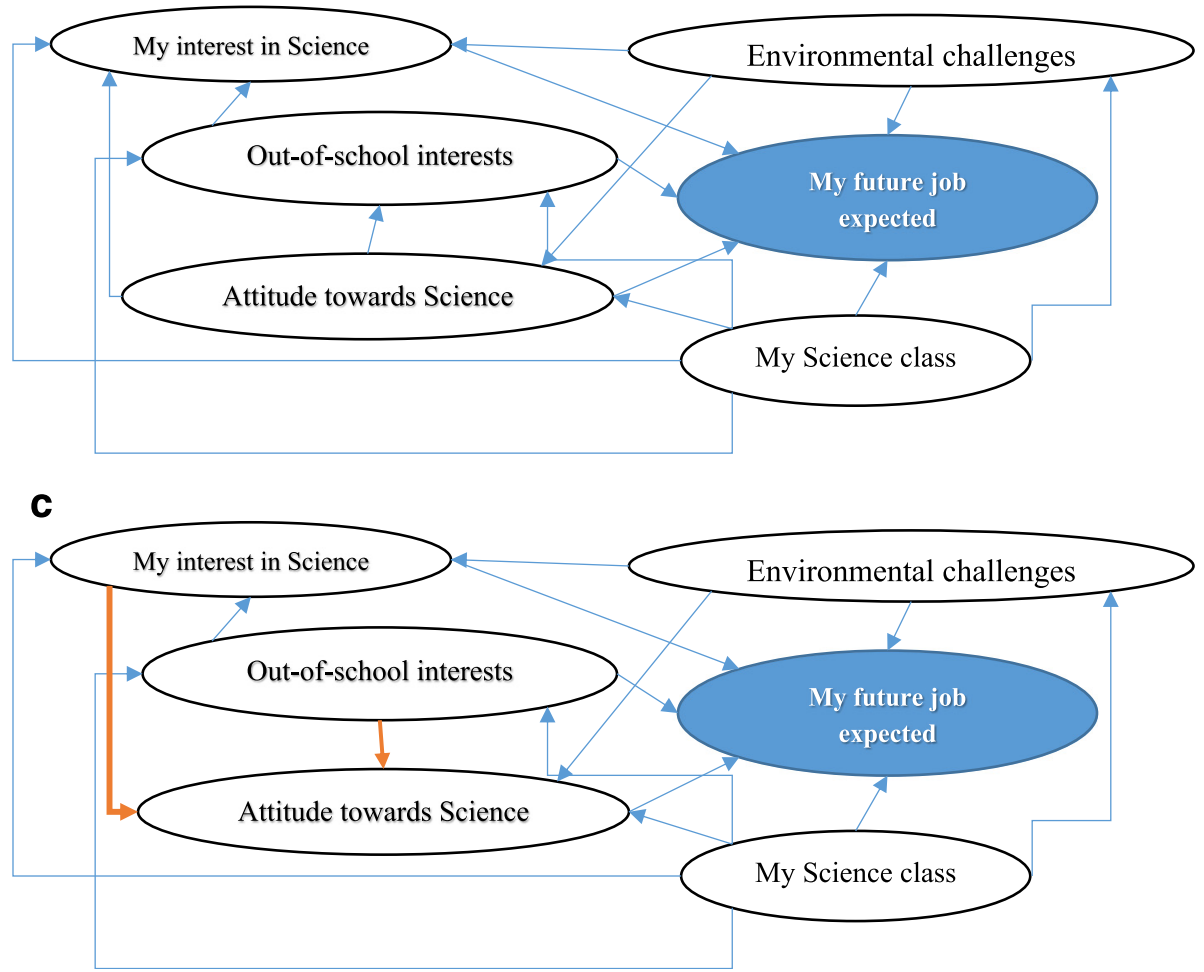

Fig. 1 a Model 1 of the determinants of (my future job expected) — general model. b Model 2 of the determinants of (my future job expected) — detailed model. c Model 3 of the determinants of (my future job expected) —-revering directions

learning about the following?" For the out-of-school activities, a total of 61 statements were presented. On a four-point scale (disagree to agree), students were asked to mark the appropriate box for "how often have you done this outside school?" There were 18 statements on environmental challenges. On a four-point scale (disagree to agree), students were asked to state their opinion regarding "to what extent do you agree with the following statements about problems with the environment?" For the "opinion about science," there were 16 statements. Students were asked "to what extent do you agree with the following statements?" There were 16 statements on my science class. On a four-point scale (disagree to agree), students were asked to "to what extent do you agree with the following statement about the science that you may have had at school?" Finally, for the expected career choices, there were 26 statements. On a four-point scale (not interested to very interested), students were asked "how important are the following issues for your potential future occupation or job?"

Through a letter written by the Director General of the ADEC to school principals in Abu Dhabi, the students were asked to participate in the study. The national and international purposes of the survey were carefully explained on a cover sheet. An online (Arabic and English) questionnaire was designed for the study. As a reminder, a follow-up letter was sent to all related school principals 2 weeks after the first letter. The 
questionnaire was made available on ADEC website for 1 month.

\section{Profile of respondents}

The responses of 5650 students (48\% girls and $52 \%$ boys) with median age of 15 years were received. For Abu Dhabi as a whole, the actual percentage of boys and girls in cycle 3 is (53.43\% girls and $46.57 \%$ boys). Compared to the percentages of sample participants, it could be said that the sample is a reasonable representations of boys and girls in Abu Dhabi cycle 3 schools. The number of students who answered the survey was $9.88 \%$ of the whole age cohort. Thus, the external validity of the present research could be evaluated to be quite high, and the sample represents the population quite well. About $53 \%$ of the students came from public school from the three educational zones in Abu Dhabi (Abu Dhabi, Al Ain, and Gharbia). About $40 \%$ of the students came from the 10th grade, $32 \%$ from the 11th grade, and $28 \%$ from the 12 th grade.

\section{Analysis methods}

The primary purpose of exploratory factor analysis (EFA) is to arrive at a more parsimonious conceptual understanding of a set of measured variables by determining the number and nature of common factors needed to account for the pattern of correlations among the measured variables (Fabrigar et al. 1999). ROSE contained large number of variables in each of its hypothesized dimensions. The most effective analysis method in this case could be EFA. Methodologists have recommended that at least three to five measured variables representing each common factor be included in a study (MacCallum et al. 1999; Velicer and Fava 1998). As a result, a data reduction method was necessary to take scores on a large set of measured variables and reduce them to scores on a smaller set of composite variables that retain as much information from the original variables as possible.

For each of the six dimensions in the study, a preliminary EFA was employed. It was used to extract as many factors as necessary to explain the correlations among the items. These factors are assumed to be the underlying causes for the inter-correlation between the items. EFA will seek to uncover what the underlying factor structure is and will carefully examine items that do not load high enough on any factor in order to determine their utility in the resulting scale. The intention was to create a small and manageable set of factors. Items with loadings below (0.60) were dropped from further analysis. In this regard, Field (2005) advocates the suggestion of Guadagnoli and Velicer (1988) to regard a factor as reliable if it has four or more loadings of at least 0.6 regardless of sample size. Of course, some like Stevens (1992) suggest using a cutoff of
0.4, irrespective of sample size, for interpretative purposes. When the items have different frequency distributions, Tabachnick and Fidell (2007) follow Comrey and Lee (1992) in suggesting using more stringent cutoffs going from 0.32 (poor), 0.45 (fair), 0.55 (good), 0.63 (very good), or 0.71 (excellent). Hair et al. (1998) suggest that loadings greater than 0.50 or greater are considered particularly significant.

Each factor was named according to the loaded items, emphasizing the contents of the factor items. Naming of factors is more of an 'art' as there are no rules for naming factors, except to give names that best represent the variables within the factors (Yong and Pearce 2003). The name of the extracted factors depends of the items retained for each of them.

SEMs comprise both a measurement model and a structural model. The measurement model relates observed responses or "indicators" to latent variables and sometimes to observed covariates (i.e., the confirmatory factor analysis (CFA) model). The structural model then specifies the relationships among latent variables and regressions of latent variables on observed variables. A measurement model is part of an SEM, which specifies the relationship between the observed and latent variables. We will use confirmatory factor analysis to test the measurement models. In the measurement model, we operationally decide the observed indicators to define the latent factors. The extent to which a latent variable is accurately defined depends on how strongly the observed indicators are related. It is apparent that if one indicator is weakly related to other indicators, it will result in a poor definition of the latent variable.

Since we conducted EFA and SEM, it was necessary to divide the whole data set into two parts. We used the first part to conduct EFA and use the second part to conduct CFA. For the SEM, we used the full data sets to conduct SEM (Abd-El-Khalick et al. 2015).

For each of the resulting dimensions from EFA (or measurement models), individual SEMs were performed using LISREL (9.2). Several fit statistics and other parameters were obtained for each. They included chi-square test $\left(X^{2}\right)$, degrees of freedom, root mean square error of approximation (RMSEA), normed fit index (NFI), nonnormed fit index (NNFI), comparative fit index (CFI), goodness of fit index (GFI), RMR, and adjusted goodness of fit index (AGFI) (Kline 2010). As a result, each dimension was further reduced to fewer factors. For each of the generated factors, the summated means and standard deviations were computed. It should be noted that factor analysis, which groups related questions into factors, can help validate a summated scale by demonstrating that its questions are related (Spector 1992). In this study, we use factor analysis to select the best questions to include in a summated scale. 
Structural models differ from measurement models in that the emphasis moves from the relationship between latent constructs and their measured variables to the nature and magnitude of the relationship between constructs (Hair et al. 2009). It defines the relationship among the latent variables. It is hypothesized that "my future job expectation" is a function of "my interest in science," "my out-of-school experiences," "my opinion about my science class," "my attitude or opinion toward science," and "how students feel about environmental challenges." The model also recognizes that there may be some perceived mediating influences of some constructs on others.

In the proposed SEM, two types of effects will be estimated: direct and indirect. Direct effects represent the relationship between one latent variable to another using single-directional arrows. Note that the arrows indicate directionality and do not imply causality. Indirect effects, on the other hand, reflect the relationship between an exogenous variable and an endogenous variable that is mediated by one or more latent variable.

A final SEM was designed using the output for each of the dimensions. The same criteria as fit statistics were used to design the final model.

\section{Results}

\section{Preliminary exploratory factor analysis}

Before the factor analysis, appropriateness of the data for the factor analysis was analyzed via Kaiser-Meyer-Olkin measure and Bartlett's sphericity test. The Kaiser-MeyerOlkin value of the scales ranged from 0.83 to 0.95 . This shows that data are appropriate for the factor analysis (Leech et al. 2005). Bartlett's sphericity test was performed to verify that the data have a multivariable normal distribution (Tabachnick and Fidell 2007). This sphericity test is significant for all the EFA models. That is, its associated probability is less than 0.05 . The probabilities ranged from 0.01 to 0.012 . These values suggest that the significance levels are small enough to reject the null hypothesis. This means that correlation matrices are not an identity matrix.

The key concept of EFA is that multiple observed variables have similar response patterns because they are all associated with a latent variable. Each factor captures a certain amount of the overall variance in the observed variables, and the factors are always listed in order of how much variation they explain. The objective here is to generate factors that capture most of the variance in the observed variables, which could then be used in other analyses. Because of the overwhelming number of variables and for the purpose of variable reduction, factors that explain the least amount of variance will be discarded. The relationship of each variable to the underlying factor is expressed by factor loading. Loadings less than (0.60) are also discarded and not considered further.
The instrument quality is ensured by the acceptable factor loadings above 0.60 and the significant $t$ value (Bagozzi and Yi 1988; Hair et al. 2009). The variables with loadings above (0.60) are retained. Such threshold constituted evidence of the convergent validity. The data analysis indicates that this measurement possessed an acceptable convergent validity, and all composite reliabilities were above 0.70 (Fornell and Larcker 1981).

Convergent and discriminant validities were evaluated using the average variance extracted. On the basis of the test's criterion, each value of average variances extracted should exceed 0.50 (Bagozzi and Yi 1988). Factor analysis of the "my interest in science - 108 variables" yielded 21 factors with $71.04 \%$ of the variance explained. Only seven factors were retained that satisfied the stringent criteria required (i.e., loading below 0.6 were excluded). For the "my future job expectation -26 variables," the EFA generated six factors with $67.83 \%$ of the variance explained. Only six factors were retained. The EFA for "environmental challenges - 18 variables" generated four factors with $64.28 \%$ of the variance explained. Only three factors were retained. The EFA of "my science class - 16 variables" yielded four factors with $83.05 \%$ of the variance explained. The EFA of "my opinion about science - 16 variables" yielded three factors with $80.44 \%$ of the variance explained. For the "out-of-school experiences - 61 variables," a total of 12 factors were generated. Only five factors were retained for further analysis. These results indicate that this study had adequate levels of convergent and discriminant validity.

Descriptive statistics (summated factor means) for each factor are shown in Table 1. For "my future job," working independently had the highest mean (3.4692), whereas working with animals and environment had the lowest mean (2.5659). The factor concerning "my interest in science," was the factor with seven components. Two items received means above the threshold (3.0): "health and exercise" with a mean of 3.5547 and "fantasy and science fiction" with a mean of 3.0876. The factor regarding "environmental challenges" found the item related to "environment is duty of everyone" getting the highest mean of 3.1531. For the factor "attitude toward science technology," the item with the highest mean score was related to "science and technology are enablers" with a score of 3.4044. The factor concerning "out-of-school experiences" generated only one item with a mean above (3.0). This item dealt with "digital applications" with a score of 3.3402. With regard to the factor of "my science class," the highest items dealt with "fond of and like science" with a score of 3.1906 and "science is interesting and challenging" with a score of 3.1226 . 
Table 1 Descriptive and fit statistics for the measurement models

\begin{tabular}{|c|c|c|c|c|c|c|c|c|c|c|c|c|c|c|}
\hline & Items & Coefficient & $t$ value & $\begin{array}{l}\text { Summated } \\
\text { mean }\end{array}$ & $\begin{array}{l}\text { Standard } \\
\text { deviation }\end{array}$ & $x^{2}$ & D.F. & RMSEA & $\mathrm{CFI}$ & $\mathrm{NFI}$ & NNFI & GFI & AGFI & RMR \\
\hline $\begin{array}{l}\text { My future expected job and } \\
\text { career }\end{array}$ & & & & & & 97.55 & 42 & 0.056 & 0.934 & 0.925 & 0.911 & 0.977 & 0.955 & 0.0345 \\
\hline Teamwork & 2 & 0.239 & 12.552 & 3.3886 & 0.71219 & & & & & & & & & \\
\hline $\begin{array}{l}\text { Leadership and control } \\
\text { management }\end{array}$ & 3 & 0.191 & 10.506 & 3.1233 & 0.81522 & & & & & & & & & \\
\hline Science and inventions & 3 & 0.307 & 15.096 & 3.4050 & 0.78256 & & & & & & & & & \\
\hline Artist/craftsman & 2 & 0.347 & 13.453 & 2.6947 & 0.91039 & & & & & & & & & \\
\hline Independent & 2 & 0.328 & 12.669 & 3.4692 & 0.70958 & & & & & & & & & \\
\hline $\begin{array}{l}\text { Working with animals } \\
\text { and environment }\end{array}$ & 2 & 0.224 & 7.631 & 2.5659 & 0.95872 & & & & & & & & & \\
\hline My interest in science & & & & & & 113.51 & 45 & 0.0290 & 0.982 & 0.974 & 0.970 & 0.992 & 0.983 & 0.0259 \\
\hline Physics and space & 3 & 0.594 & 20.018 & 2.8732 & 0.81784 & & & & & & & & & \\
\hline Agriculture and farming & 3 & 0.509 & 17.998 & 2.5938 & 0.96947 & & & & & & & & & \\
\hline Physiology and human body & 3 & 0.304 & 12.361 & 2.9633 & 0.86245 & & & & & & & & & \\
\hline Health and exercise & 2 & 0.388 & 13.081 & 3.5547 & 0.89627 & & & & & & & & & \\
\hline Digital and engineering & 3 & 0.426 & 14.901 & 2.8283 & 0.98307 & & & & & & & & & \\
\hline Fantasy and science fiction & 4 & 0.439 & 14.152 & 3.0876 & 0.96244 & & & & & & & & & \\
\hline Chemical and nuclear & 2 & 0.374 & 13.288 & 2.8799 & 0.91977 & & & & & & & & & \\
\hline $\begin{array}{l}\text { Me and environment } \\
\text { challenges }\end{array}$ & & & & & & 1.928 & 6 & 0.0191 & 0.998 & 0.991 & 0.990 & 0.998 & 0.994 & 0.0158 \\
\hline $\begin{array}{l}\text { Personal environment duties } \\
\text { of everyone }\end{array}$ & 3 & 0.370 & 19.772 & 3.1531 & 0.79643 & & & & & & & & & \\
\hline $\begin{array}{l}\text { Positive views about the } \\
\text { environment }\end{array}$ & 3 & 0.335 & 16.608 & 3.0037 & 0.83549 & & & & & & & & & \\
\hline $\begin{array}{l}\text { Pessimistic views of } \\
\text { environment }\end{array}$ & 2 & 0.331 & 10.020 & 2.9562 & 0.83109 & & & & & & & & & \\
\hline $\begin{array}{l}\text { Opinion about science/ } \\
\text { technology }\end{array}$ & & & & & & 14 & 6 & 0.052 & 0.989 & 0.987 & 0.973 & 0.995 & 0.981 & 0.0179 \\
\hline $\begin{array}{l}\text { Science and technology } \\
\text { (enablers) }\end{array}$ & 3 & 0.322 & 6.4480 & 3.4044 & 0.73099 & & & & & & & & & \\
\hline $\begin{array}{l}\text { Science is solution to } \\
\text { many things }\end{array}$ & 2 & 0.386 & 10.014 & 2.8393 & 0.89964 & & & & & & & & & \\
\hline Science/technology and health & 2 & 0.304 & 5.441 & 3.1219 & 0.79803 & & & & & & & & & \\
\hline My out-of-school experiences & & & & & & 76.83 & 33 & 0.030 & 0.987 & 0.982 & 0.977 & 0.993 & 0.985 & 0.0290 \\
\hline $\begin{array}{l}\text { Learning science by } \\
\text { observation }\end{array}$ & 4 & 0.502 & 12.337 & 2.9389 & 0.88598 & & & & & & & & & \\
\hline Home cooking & 2 & 0.414 & 10.983 & 2.9550 & 1.01894 & & & & & & & & & \\
\hline Experimental (educational toys) & 2 & 0.508 & 15.075 & 2.6852 & 0.96926 & & & & & & & & & \\
\hline Digital applications & 4 & 0.476 & 11.423 & 3.3402 & 0.86514 & & & & & & & & & \\
\hline The natural world & 3 & 0.388 & 8.947 & 2.3986 & 0.98604 & & & & & & & & & \\
\hline My science class & & & & & & 29.001 & 11 & 0.0427 & 0.987 & 0.984 & 0.975 & 0.993 & 0.982 & 0.0245 \\
\hline Fond of and like science & 3 & 0.525 & 34.729 & 3.1906 & 0.79399 & & & & & & & & & \\
\hline Science is easy (smart) & 2 & 0.530 & 26.756 & 2.7957 & 0.93962 & & & & & & & & & \\
\hline Science related career & 3 & 0.591 & 23.855 & 2.8141 & 0.96839 & & & & & & & & & \\
\hline $\begin{array}{l}\text { Science is interesting } \\
\text { and challenging }\end{array}$ & 2 & 0.460 & 17.681 & 3.1226 & 0.87480 & & & & & & & & & \\
\hline
\end{tabular}




\section{The measurement models}

While the latent variable model summarizes the theoretical relationships among the latent variables that a researcher has hypothesized, these relationships can only be tested if measures of the latent variables are collected such that these observed variables are proxies of the latent variables. The measurement model links the latent variables with observed variables (the terms observed variables, indicators, measures, and manifest variables are interchangeably used).

To evaluate a measurement model, a considerable number of statistical measures have been developed, which can be applied to any SEM. These measures exist to determine the validity of the hypothesis. All six measurement models were subject to structural equation modeling using (LISREL 9.2). Both subjective and objective criteria were used to identify the final measurement models for consideration into the overall SEM model for this study.

In addition to the aforementioned fit statistics, other means were used. For example, we looked at the standardized residual covariances. Variables or items with relatively low loadings were removed. Many checks were performed for values above (2.58) on an absolute scale (Jöreskog and Sörbom 1993). Since we cannot covary variables, we tried to get rid of variables that were causing problems. We looked at residuals to check for discrepancies between the proposed model and the estimated model. We also let the covariances of certain variables to be correlated as suggested by others (Schumacker and Lomax 2010). These tests caused many variables to be deleted from further considerations. The final output is provided in Table 2 .

The goodness of fit of the measurement structural models was evaluated using many statistics obtained from LISREL. The $\chi 2$ test, NFI, NNFI, CFI, RMSEA, GFI, and AGFI have been applied to the evaluated model finesses (Jöreskog and Sörbom 1993). Results from Table 2 show that all values are within the threshold suggested by other researchers (Schumacker and Lomax 2010; Jöreskog and Sörbom 1993). The table also shows the final number of items remaining in each of the factors and dimensions.

\section{SEMs}

The relationships among variables were constructed and verified through the SEM. Three different SEM models were run. For the general SEM (Fig. 1a), the analysis yielded the following fit statistics: $\chi^{2}$ of 932.16, degrees of freedom is 149, RMSEA is 0.048 , CFI is 0.9644 , NFI is 0.891 , NNFI is 0.881 , GFI is 0.958 , AGFI is 0.94 , and RMR is 0.024 . There are some problems with regard to NFI and NNFI as they are both below the accepted threshold. Moreover, $\left(\chi^{2} /\right.$ degrees of freedom $)$ is 6.256 which is too high. The second model (Fig. 1b) reverses some of the directions (my science and attitude toward science) and (out-of-school interests and attitude toward science). Testing these models will provide the true effect directions. Results of the final SEM with standardized path coefficients are shown in Fig. 2. This model yields an acceptable fit statistics $\left(\chi^{2}\right.$ of 534 , degrees of freedom is 184, RMSEA is 0.0447 , CFI is 0.9644 , NFI is 0.953, NNFI is 0.9494, GFI is 0.957, AGFI is 0.942, and RMR is 0.0240$)$. The value of $\left(x^{2} /\right.$ degrees of freedom $)$ is 2.90 which is acceptable. Table 2 shows the path estimates and $t$ values for the significant paths only in the model. The third model (Fig. 1c) provided the following fit statistics: $\chi^{2}$ of 1150, degrees of freedom is 152, RMSEA is 0.054, CFI is 0.881, NFI is 0.866, NNFI is 0.851 , GFI is 0.928 , AGFI is 0.900 , and RMR is 0.0259 .

Table 2 Significant paths, direct estimates, and $t$ values

\begin{tabular}{lllrr}
\hline Path from & & Path to & Estimates & 0.577 \\
\hline My interest in science & $\rightarrow$ & My future job & 0.251 & 7.506 \\
My science class & $\rightarrow$ & My future job & 0.513 & 3.143 \\
My attitude toward science & $\rightarrow$ & My future job & 0.143 & 4.341 \\
My out-of-class experience & $\rightarrow$ & My future job & 0.264 & 2.225 \\
Environmental challenges & $\rightarrow$ & My interest in science & 0.529 & 3.606 \\
My science class & $\rightarrow$ & My interest in science & 0.298 & 15.772 \\
My attitude toward science & $\rightarrow$ & My interest in science & 0.279 & 3.663 \\
My out-of-class experience & $\rightarrow$ & My interest in science & 0.640 & 4.698 \\
My attitude toward science & $\rightarrow$ & My out-of-class experience & 0.527 & 16.739 \\
My science class & $\rightarrow$ & My out-of-class experience & 0.559 & 16.637 \\
My science class & $\rightarrow$ & Environmental challenges & 0.403 & 16.792 \\
Environmental challenges & $\rightarrow$ & My attitude toward science & 0.800 \\
My science class & $\rightarrow$ & My attitude toward science & 23.980 \\
\hline
\end{tabular}




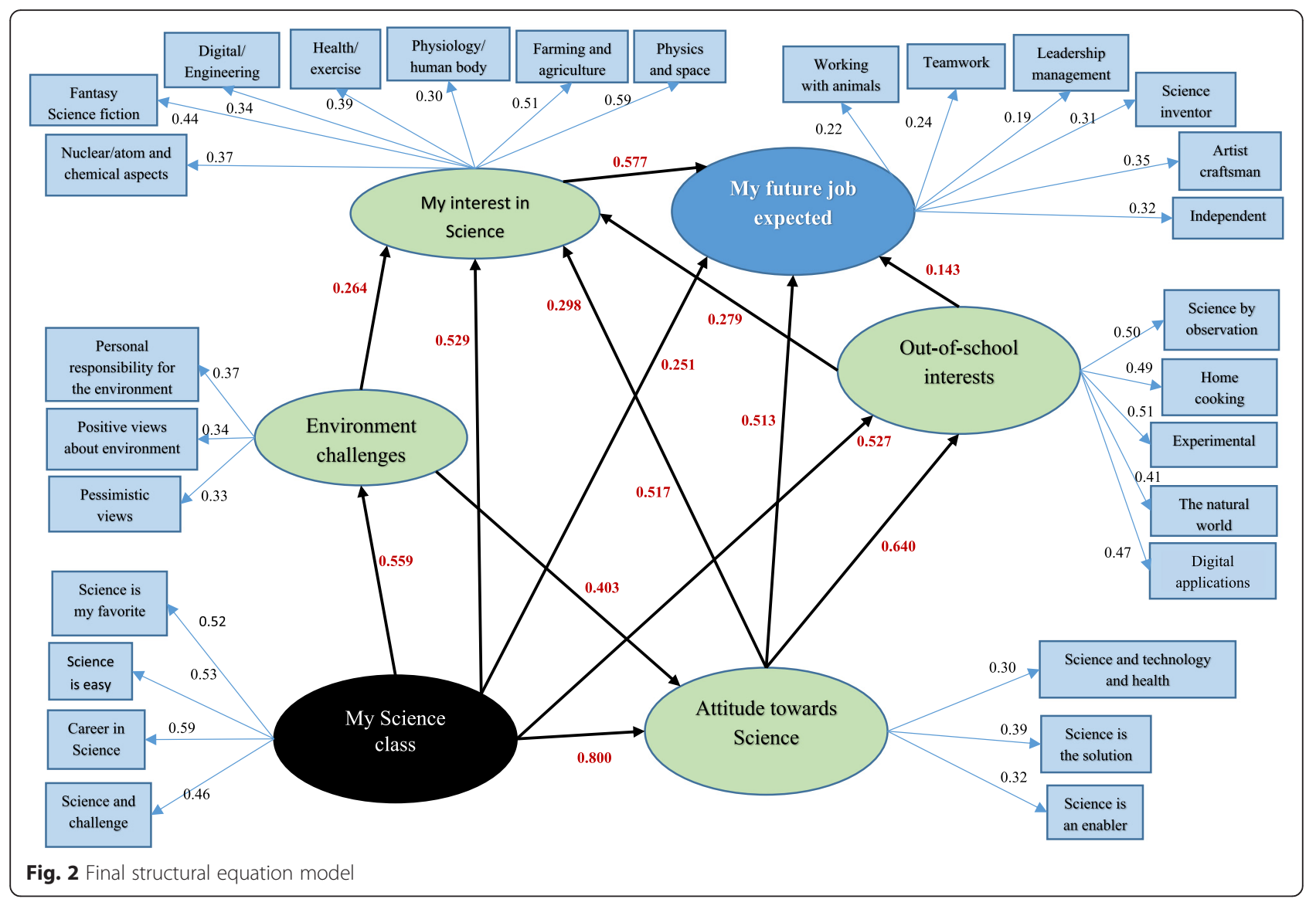

Results provide unacceptable low values for CFI, NFI, and NNFI. The value of $\left(\chi^{2} /\right.$ degrees of freedom) is 7.656 which unacceptably too high. Results of these tests provide statistical justifications for selecting the detailed model in Fig. 2 (or summary model in Fig. 1b) to be the best representative model for Abu Dhabi.

The SEM analysis reveals several noteworthy results:

(1) "My science class" created significantly positive effects on "my future job" and the other four latent variables in the model. It exhibited the highest significant effect on "attitude toward science" with an estimate of (0.800) and a $t$ value of 23.773. With regard to "my future job," it had a significant but modest value of 0.251 with a $t$ value of just 3.143 . It seems also that "my science class" significantly affects what students are interested in doing out-of-school with an estimate of 0.527 and a $t$ value of 16.637. Moreover, it significantly affects what students are interested to learn about with an estimate of 0.529 and a $t$ value of 5.772. It also exerts significant influence on how students regard "environmental challenges" with a high estimate of 0.559 and $t$ value of 16.792 .
(2)However, Fig. 2 shows that "my science class" has an indirect effect on "my future job" through many other paths. It has an indirect effect through "environmental challenges" to "my science interest" and then to "my future job" for a total indirect effect of 0.08515. It also has an indirect effect through "my interest in science" for a total indirect effect of 0.3052. In addition, it influences "my future job" through "attitude toward science" and out-of-school experiences (0.0732). Finally, it has an indirect effect of 0.0754 through out-of-school experiences. As a result, it has an overwhelming total effect of 0.79195 on "my future job" (for indirect effects, asymptotic methods are used).

(3) "My science interests" or "what science topics I am interested to learn about" significantly affects "my future job." The analysis results in an estimate of 0.577 with a $t$ value of 7.506. It is also interesting to note that students' interest in certain science topics is affected by other factors such as opinion about environment challenges (estimate $=0.264$, $t=3.606$ ), out-of-school experiences (estimate $=0.279$, $t=4.698$ ), and "my science class" as mentioned earlier. 
(4)With regard to "my out-of-school experiences," besides its modest influence on "my interest in science," it has a significant but low influence on "my future job" with an estimate on 0.143 and a $t$ value of 2.225 .

(5)It seems that "my future job" is influenced by all dimensions except students' attitude or opinion about science (no significant path is recorded). However, opinion about environmental challenges indirectly affects "my future job" through "my interest in science" with an effect of 0.1523 .

(6) Students' attitude about science has significant influence on what students like to study, his/her future job expectation, and what he/she likes to do as out-of-school experiences. It has a direct effect of 0.513 on "my future job" and an indirect effect of 0.09151 through out-of-school interests and 0.1714 through "my interest in science" for a total effect of 0.7759 .

Table 3 shows the indirect effects of each of the four constructs on "my future job." Results show that the largest effects are due to "my science class" with a total effect of 0.79195 , "my attitude toward science" with a total effect of 07590, and "my interest in science" with a total effect of 0.5770 . On the other hand, both "my out-ofschool experiences" and opinion about environmental challenges result with a combined total effect of 0.2953 .

\section{Discussion}

The structural equation modeling used in this study focuses a great deal on latent variables where we are unable to measure them directly and rely on measurable indicators. The model was capable of operationalization of data as an abstract construct referring to other hidden and integrative indications. When we tested each of the factors (or measurement models), we showed, for example, that "my future job" is not measured directly and it is hypothesized to cause covariation among a set of other measured variables (six variables) and so on for the other five factors of "my science class," attitude toward science," "out-of-class experiences," "interest to learn science," and "environmental challenges." The SEM presented in this study confirms that students' interests, attitudes, self-efficacy beliefs, and images of science exert direct and indirect effects on students' perception of future job or career expectation. The results are consistent with other studies (Dimopoulos and Smyrnaiou 2005). A linkage of these constructs with students' career choices and personal and social lives has also been reported (Britner 2008; Schibeci and Lee 2003). Students' "interest in science" is significantly influenced by "my science class" with a 0.529 parameter strength. The results from the current study also indicated antagonistic attitudes of students toward school science. It became evident that school science is rather difficult to learn $($ mean $=2.7957)$. This result is consistent with other research studies (Black and Atkin 1996; Chen et al. 2016). However, students thought that school science is interesting and challenging (mean of 3.1229). The study of Yager and Yager (1985) shows similar results.

The results help explain how students experience science education in their class, what sort of attitude start to shape, and what kind of activities they practice outside the school. The study shows that generally, lifeoriented topics and those that help in real-life situations are preferred. Results are similar to those obtained by other researchers (Kier et al. 2016; Tyler-Wood et al. 2010; Tsabari and Yarden 2005; Miller et al. 2006). The direct effect of "my science class" on "my future job" recorded a significant but relatively low value of 0.251 with a $t$ value of 3.143. In general, results are consistent with similar studies in other cultures (Samara 2015; Aldridge et al. 2000). However, structural equation modeling provided means for calculating the true effect of "my science class" on "my future job" by revealing some hidden or indirect effects through other mediating constructs. Results show that students being interested in a science-related career are a result of the "interaction" among multiple complex factors. Results also confirm that as with other studies in Abu Dhabi schools, the issue has become firmly linked to young people's disengagement with STEM subjects in school and their decreasing interest in STEM careers (Jenkins and Nelson 2005; Sjøberg and Schreiner 2010; Reid 2003). Such multiple linkages confirm previous results that career

Table 3 Direct, indirect, and total effects in the final SEM model

\begin{tabular}{llllll}
\hline Path from & & Path to & Direct effect & & Indirect effect \\
\hline My interest in science & $\rightarrow$ & My future job & 0.577 & - & Total effect \\
My science class & $\rightarrow$ & My future job & 0.251 & 0.54095 & 0.57700 \\
My attitude toward science & $\rightarrow$ & My future job & 0.143 & 0.26290 & 0.79195 \\
My out-of-class experience & $\rightarrow$ & My future job & 0.143 & - & 0.14300 \\
Environmental challenges & $\rightarrow$ & My future job & - & 0.15230 & 0.15230 \\
\hline
\end{tabular}


choices in STEM are a complex phenomenon, where multiple factors interplay (Bottiaa et al. 2015; Cleaves 2005; Lavonen, Byman, et al. 2008a, 2008b).

Results show that science class and attitude have influence on out-of-class experience, and out-of-school class has influence on science interests. In some way, the findings are different than Semela (2010), who suggests that science class experience, including curricula, textbooks, teachers, and teaching practices, are crucial factors that affect students' attitudes toward an interest in science.

The multiple linkages between out-of-school experiences and many other constructs suggest that some of the most effective STEM activities occur in more informal learning contexts with significantly more activities being science centered. Results show that both "my science class" and "my attitude toward science" significantly affect "my out-of-school experiences." Results are in line with results obtained in other countries for the linkage of "my future job" and "my interest in Science" (Wang and Staver 2001; Kniveton 2004; VanLeuvan 2004). Results also show that "my out-of-school experiences" affect both "my future job" and "my interest to learn science." For Abu Dhabi, it seems that linking school science with students' out-of-school science experiences would enhance students' interest in science requires re-examination of traditional school science in terms of content, instructional practices, textbooks and support facilities, teacher preparation, and assessment of further research. Establishing such a system is also called for by many studies (Gafoor and Smitha 2012; Uitto et al. 2006; Trumper 2006a). This might also involve exploring the living and non-living things and playfully interacting with their environment help children learn as called by many. It seems that ADEC could encourage its curriculum division to decide the major concepts and identify the corresponding locally available out-of-school experiences. For achieving the affective goals of education, the most appropriate, responsive, relevant, and reliable curriculum is limited in scope. Such projects might lead to further modification of textbooks to make them as extensions of out-of-school experiences with interesting ideas, references, and activities.

School experience, the way science is taught in classroom and beyond, could make a difference across social boundaries and is a factor that could be more rapidly improved. Consistent with other studies (Schibeci and Lee 2003; Scherz and Oren 2006), the present results shows how school experience of STEM could make a crucial difference in young people's predisposition to STEM learning and careers. In the case of Abu Dhabi, STEM enhancement and enrichment activities might be seen as a mechanism for generating interest in the subjects. Informal STEM learning activity such as visits should be more explicitly linked to careers. There should also be more enrichment and enhancement opportunities in mathematics, design and technology, and engineering. As a regulator of education in Abu Dhabi, this also calls on ADEC to incorporate in its strategic plan for schools some KPIs to encourage schools to help establish an environment in which STEM careers activity can take root and flourish.

Analysis of this study reinforces the previously noted thought that the individual choice for a science-related career is determined by multiple factors that also involve school science and the collaboration and support of the STEM teachers (Faitar and Faitar 2013; Kniveton 2004; VanLeuvan 2004). Results point to the fact that a high level of expertise equating with the orientation toward science jobs in demand is to be sustained by both teachers and students.

As of the academic year 2015, there is no career staff (or career planning staff) in schools in Abu Dhabi. However, an entire related system is about to start in 2016. ADEC should understand that careers staff seemed better able to make a positive contribution when they felt they had an appropriately high-status role that enables them to support the development of careers within all subject areas, especially STEM-related ones. Career guidance in schools should be independent, though this should not result in students having restricted access to information in a misplaced interpretation of impartiality. Mechanisms should be put in place to ensure impartiality, so that young people are not channeled toward specific institutions and that their future long-term interests feature at the core of the experience. Many young people have preconceptions of STEM careers as difficult or dull, and it is right that schools challenge these views. Often, it is the attitudes of parents that lead to these entrenched and stereotypic beliefs. Schools that develop and implement approaches to engage parents in the STEM agenda are more likely to achieve success with their learners. Industry placements for teachers, the development of long-term relationships with local employers, and skilled mediation of high-quality labor market information can individually contribute to promoting careers from STEM subjects without undermining impartiality. Career progression data could also be used by schools to present a local dimension to national and regional labor market information as well as highlight many different routes to successful careers.

Consistent with other studies (Christidou 2006; Koosimile 2004; Clewell and Campbell 2002), it is interesting to note that students did see a connection between out-of-school experiences and future jobs, but this connection could be said to be relatively weak. This contradicts many of the research reviewed here. It seems that the out-of-school experiences of these studies were not rich enough to support them to make informed decisions about their 
future work career. In the case of Abu Dhabi, teachers are recommended to incorporate out-of-school experiences in their plan efficiently and thus enhance students' interest and achievements in science. Gafoor and Smitha (2012) also recommended that it will be highly helpful if experiences that are most significant in developing students' interest during primary school years are identified.

It seems that "my science class" affected all the other five constructs in one way or another. It exhibited the maximum influence as it is the main cause for shaping students' "attitude toward science" with a 0.80 parameter strength. It also exerted significant influences on students' interest with regard to out-of-school activities. "My science class" also seems to provide directions on how students perceive "environmental challenges" with a 0.559 parameter strength. The overall significant influence of "my science class" on multiple dimensions related to science learning is also evident in other studies (Hatzinikita 2007; Buck et al. 2009; Unlu et al. 2016).

For Abu Dhabi STEM subject teachers, the importance of professional development as it relates to career ambitions is evident. As found in the other studies (Gough 2002; Kelly 2000; Siegel and Ranney 2003), professional development should focus on building their knowledge and understanding of careers and the related STEM labor market so that they are better able to support students' career-related learning.

Results confirm the influence of students' attitude toward science on the selection of "out-of-school activities," "interest in science," and "my future job." Self-efficacy is the lynchpin in social cognitive career theory (Lent et al. 1994; Wang 2013; Crisp et al. 2009). This theory stresses that students' internal beliefs, attitude, and experiences combine to influence their ideas and expectations about their own capabilities with respect to STEM. Ultimately, in order to persist in STEM, students must have a positive attitude toward science and believe that they are capable of successfully completing the required education and training and carrying out job duties once in the field.

The interest to learn science significantly affected "my future job" and was itself influenced by four other constructs: "environmental challenges," "my science class," "attitude toward science," and "out-of-class experiences." In other words, STEM careers could attribute to their early decisions to take high school STEM courses to a positive attitude and experiences with science. In addition, informal STEM activities help maintain students' positive attitudes about STEM throughout schooling (Hossain and Robinson 2012; Miller and Solberg 2012; VanLeuvan 2004; Rennie 2005; Tisdal et al. 2005; Kim and Song 2010).

\section{Implications for science curriculum in Abu Dhabi}

For Abu Dhabi, the findings of this study, when taken collectively, provide powerful implications for reframing of the science curriculum at the basic level. There is therefore a clear message to curriculum designers in this regard that we cannot ignore voice of the students themselves in promoting quality science education in Abu Dhabi.

The objectives of this study are to give a fresh impetus to the debate on science curriculum reforms for the high school level in order to serve the needs of students. In general, the voice of students is clearly missing from the constitutive voice in the science curriculum formulation. There are some aspects of science both contextual and content-wise that students perceive to be relevant to their everyday lives, such as health, career choice, and environmental challenges. What learners regarded as relevant and how they have responded to this relevance in this study will require a type of science curriculum that will facilitate the delivery of relevant science, including the relevance of context, purpose, and method. A curriculum whose content is partly determined, or at least influenced by the expressed needs and interests of the students, may generate a curriculum more relevant to them. We already cited many research projects in this study, pointing to conclusions that designing a science curriculum that is closer to students' interests may change their attitudes to and learning of the subject. However, attempting to rework the science curriculum according to the values and interests of students is not meant to devalue the high-quality accepted science. School science could appear more meaningful to students when the science curriculum considers to some extent the students' values they hold for school science.

For Abu Dhabi, to be more objective, future research should try to explore the effect of some other variables on student's interest in Science. The shorter version of ROSE identified in the current study could be used. The study could serve as validations for results in other studies in other cultures (i.e., the significant differences according to gender (Reid 2003; Christidou, 2006; Osborne and Collins 2001) and according to student age or grade level (Bowtell 1996; Trumper 2006b).

For Abu Dhabi, results of this study emphasize that it is important for school science education to prepare school graduates adequately for a meaningful future in order to fully participate in the social and economic development of the country. The study shows that the current focus of interest on technological matters is of central interest to both boys and girls. Some change in content and style of teaching to some extent would lead to a significant increase in the choice of variety of science disciplines for boys and girls. The important goals of relevant science education are to recognize the perceived needs and interests of the Abu Dhabi learner, the needs of the Abu Dhabi society in which science is embedded, and prepare and equip learners for future occupation. Furthermore, it must relate more to social issues in order to promote interest in science. 
Limitations and recommendations for further research

Future follow-up research might consider including other factors that influence the learning of science, such as parent influences, peer influences, and teacher-student interaction. The current study involved a representative number of students from all Abu Dhabi high school students. Although the selected schools covered all economic areas of Abu Dhabi, future studies should look for a larger sample.

The ROSE instrument might have been limited in the types and number of items that students had available for selection. Different items more relevant to the Abu Dhabi society could lead to different conclusions regarding students' science experiences and future career expectations. An interview approach in a study of this nature in future might be advisable to enhance data quality and obtain a better interpretation of results. Adopting a combination of quantitative and qualitative interview-based approach seeking to explore students' views of their experience of school science might add fresh insights into its nature and quality.

Since ROSE included environmental challenges, it was necessary to just include it in the analysis. Many might question the idea of environmental challenge in this context to be abrupt. There are so many other STEM related issues that could have been added too. Why only chose environmental challenges? This concern might also raise many questions since results of this study showed that generally, life-oriented topics and those that help in real-life situations are preferred by students. We might assume that the inclusion of environment issues in the survey lead to the rise of such conclusion. As a result, it might be inadequate to make a claim that environmental challenges have influence on students' science attitude and interests without considering other variables that were not included in the survey from the beginning.

We understand that the results of this study might guide the ongoing debate among the science education research community in Abu Dhabi on the search for a combination of international and local science curriculum that to some degree recognizes the voice of learners who are the beneficiaries of the school science.

It is important that we are cautious about picking on science curriculum in a direct way. Both the results and the limitations of the study suggest that there are many factors that could contribute to a quality science class experiences. For example, a good science curriculum also needs a good teacher who knows how to teach it. Education system is a complex system. Science curriculum is one but not the only one issue in K-12 education. Policy makers need to be more inclusive to provide appropriate suggestions in order to improve students' class experience.
Many studies have pointed out that while academic preparedness generally depends on a strong secondary school academic program, non-classroom experiences with STEM, the attitudes of family and peers, and young people's personal qualities also contribute to students' persistence in STEM. Young people need parents who are encouraging, a peer network that supports students' achievements, and mentors or counselors who can explain the meaning of the choices that students face (Cleaves 2005; Scott and Mallinckrodt 2005). A variety of reports suggest reasons students may hesitate to pursue STEM courses and careers, including a lack of quality preparation in mathematics and science in K-12 educational systems, lack of access to money and technology, lack of guidance from adults who are knowledgeable of or are affiliated with STEM careers, psychological barriers (such as believing mathematics and science are too difficult), and lack of role models in the fields (Turkmen 2008; Quita 2003). Future research should look into all these factors and explore how they interact to lead to a STEM future job for students.

\section{Conclusions}

Much of the literature reviews were based on research conducted in other countries and mostly Western countries. Some might wonder if it was necessary to conduct the same for research in Abu Dhabi too. However, it should be noted too that there is some scarcity of similar research in Abu Dhabi. In the new strategic plan for ADEC, STEM education takes center stage. As a result, extensive research is needed to establish sound and objective goals and strategies. The current research used ROSE as an instrument but utilized careful statistical models such as EFA, CFA, and SEM to fine tune ROSE to fit the Abu Dhabi education environment. Many items in ROSE dropped out as a result. In addition, a team of teachers and advisors in ADEC analyzed the applicability of ROSE in Abu Dhabi. From the discussions, it was stressed that ADEC uses its own curriculum in Science; however, the curriculum is mostly taken from other world-class education systems such as the USA, the UK, Finland, Singapore, and South Korea. Even though, these cultures are different from each other, but they do have commonalities when it comes to the Science curriculum. ROSE was carefully designed to be appropriate for most cultures in the world. More than 40 countries participated in the project. These countries also included some Arab countries such as Egypt and Lebanon. As a result, ROSE was judged to be appropriate for Abu Dhabi too.

The main purpose of this study was to elicit, describe, design, test, and analyze the Abu Dhabi high school students' experiences, interests, priorities, expectations, and images that are of relevance to the learning of science. 
The research explored a range of affective factors that might have a bearing on science education. This was made possible through the invitation of a sample of 5650 high school students in Abu Dhabi to complete a ROSE survey designed questionnaire. The study elicited students' science topics of interest, views about environmental challenges, relationships with school science, opinions about science and technology, priorities of future jobs, and out-of-school science experiences. The study resulted in a comprehensive framework and model of factors and determinants that demonstrate an overall linkages and relations to better understand what might trigger students to think about their expected future careers. A careful review of the numerous paths in the model (in Fig. 2) would reveal many interesting insights into the interaction of the several variables included in this analysis. The essential advantages of using SEMs are that we could obtain accurate summary measures of the total effect of each of the variables in the analysis.

The research attempted to interpret and discuss the results by drawing on literature from science education research and a theoretical framework of the ROSE model. However, to provide informative discussion, one should link results to other disciplines such as sociology, psychology, and research on youth. As researchers of this study, we admit that venturing into different disciplines needs to be done with caution when one's knowledge base is limited. This has been our major reason for keeping within science education research arena.

The results of this study are expected to contribute to the public and policy-making professionals our understanding of the complex linkages that shape up students' attraction toward a specific career, in particular a sciencerelated career. Our research shows that just making science lessons interesting or informing students about social significance of STEM is not enough to sway young people toward STEM careers. While a majority of students see science lessons as "fun" and agree that STEM is very important for society and a useful qualification to have, many do not relate to STEM careers.

The Abu Dhabi policy agenda 2030 stresses that STEM should be the primary driver of the future economy and concomitant creation of jobs that is based on innovation, largely derived from advances in science and engineering. An increasing number of expected jobs at all levels require knowledge of STEM. In addition, individual and societal decisions increasingly require some understanding of STEM, from comprehending medical diagnoses to evaluating competing claims about the environment to managing daily activities with a wide variety of computer-based applications. In summary, the policy has linked STEM education to continued scientific leadership and economic growth in Abu Dhabi. Meanwhile, ADEC has embarked on an aggressive strategic agenda for K-12 STEM education in the Abu Dhabi that captures the breadth of the purposes for STEM education and reflects the types of intellectual capital needed for the nation's growth and development in an increasingly science and technology driven world.

The empirical evidence from this study can inform the science education community in Abu Dhabi and, perhaps, similar cultures in the science education research arena. For Abu Dhabi in particular, the significance of the results will be evident in the ongoing debate on some topical issues in science education policy-making for strategies related to science curricular content, curricular delivery methods, teacher preparation and professional development, class management and delivery methods, and other socio-scientific issues such as science and technology careers, environmental challenges, gender, socioeconomic status of parents, and experiences outside school time activities in relation to science education. Similar to other studies involving ROSE, results of this study should provide a rich arena for encouraging informed discussions by stakeholders.

Most of the ROSE-related research published so far tried to use simple descriptive analysis such as means, standard deviation, or analysis of variances (Sjøberg and Schreiner 2010). Some studies used EFA to come up with meaningful item reduction and categorization of the various dimensions (Jones et al. 2000). In addition, some others attempted to use confirmatory factor analysis for the conformation of measurement models (Christidou 2006). All these studies focused on students' interest in sciencerelated subjects and attempted to correlate those interests with other factors related to students' opinions about science classes, their out-of-school experiences in sciencerelated activities, their future career expectations, and their attitudes toward science and technology (Uitto et al. 2006). Some studies used correlation analysis to shed light on the scale of correlation between the various dimensions used in ROSE (Gafoor and Smitha 2012). The current study goes one step further in an attempt to link the various dimensions in a unified SEM to better understand the complex effects of the various elements on each other.

\footnotetext{
Acknowledgements

The authors would like to thank the Director General of the Abu Dhabi Education Council, Dr. Ali Rashid Al Nuaimi, for providing the support by writing a letter (and a follow-up reminder) to all school principals to encourage the children to participate in the study. We also thank all teachers in both public and private schools in Abu Dhabi for their support.
}

\section{Authors' contributions}

$\mathrm{MB}$ carried out the conception and the design of the work. He also carried out the analysis of the data and provided the final approval of the version to be published. JM carried out the interpretation of the analysis of the data and provided some critical revision of the article. Both AA2 and GY designed the online survey and performed the data collection; they also helped in performing some statistical analysis. KM performed some critical revision of the article; she also participated in the sequence alignment and drafted the manuscript. All authors read and approved the final manuscript. 


\section{Competing interests}

The authors declare that they have no competing interests.

\section{Author details}

${ }^{1}$ Research \& Planning, Abu Dhabi Education Council, Abu Dhabi, United Arab Emirates. ${ }^{2}$ Abu Dhabi Education Council, Abu Dhabi, United Arab Emirates. ${ }^{3}$ Strategic Planning Division, Abu Dhabi Education Council, Abu Dhabi, United Arab Emirates. ${ }^{4}$ Department of Education, UAE University, Al Ain United Arab Emirates.

\section{Received: 6 December 2015 Accepted: 4 July 2016}

Published online: 21 July 2016

\section{References}

Abd-El-Khalick, F., Summers, R., Said, Z., Wang, S., \& Culbertson, M. (2015). Development and large-scale validation of an instrument to assess Arabic speaking students' attitudes toward science. International Journal of Science Education, 37(16), 2637-2663.

Aikenhead, G. S. (2005). Science-based occupations and the science curriculum: concepts of evidence. Science Education, 89, 242-275. Also available online: http://www.interscience.wiley.com. Accessed Jan 2016.

Aldridge, J., Fraser, B., Taylor, P., \& Chen, C. (2000). Constructivist learning environments in a cross-national study in Taiwan and Australia. International Journal of Science Education, 22, 37-55.

American Institute of Physics. (2014). High school physics courses \& enrollments, June (2014). Retrieved from https://www.aip.org/sites/default/files/statistics/ highschool/hs-courses-enroll-13.pdf. Accessed May 2015.

Anderson, I. (2006). The relevance of science education: as seen by students in Ghanaian junior secondary schools. Doctoral thesis. University of the Western Cape, Department of Mathematics and Science Education.

Anderson, I. K., Sjøberg, S., \& Mikalsen, O. (2006). What kinds of science and technology do students in Ghanaian junior secondary schools want to learn about? Some results and comparisons based on the international ROSE study. In C. Julie \& O. Mikalsen (Eds.), Some developments in research in science and mathematics education in Sub-Saharan Africa. Cape Town: University of Western Cape.

Bagozzi, R. P., \& Yi, Y. (1988). On the evaluation of structural equation models. Journal of the Academy of Marketing Science, 16, 74-94.

Baram-Tsabari, A., \& Yarden, A. (2005). Characterizing children's spontaneous interests in science and technology. International Journal of Science Education, 27(7), 803-826.

Bennett, J. (2003). Teaching and learning science: a guide to recent research and its applications. London: Continuum.

Bennett, J., \& Hogarth, S. (2005). Would you want to talk to a scientist at a party? Students' attitudes to school science and science. York: University of York, Department of Educational Studies.

Bianchini, J. A., Johnston, C. C., Oram, S. Y., \& Cavazos, L. M. (2003). Learning to teach science in contemporary and equitable ways: the successes and struggles of first-year science teachers. Science Education, 87, 419-443.

Black, P., \& Atkin, J. (1996). Changing the subject: innovations in science, mathematics and technology education. London: Routledge for OECD.

Bogner, F., \& Wiseman, M. (2004). Outdoor ecology education and pupils' environmental perception in preservation and utilization. Science Education International, 15(1), 27-48.

Bottiaa, M., Stearns, E., Mickelsonb, R., Moller, S., \& Valentino, L. (2015). Growing the roots of STEM majors: female math and science high school faculty and the participation of students in STEM. Economics of Education Review, 45, 14-27.

Bowtell, E. (1996). Educational stereotyping: children's perceptions of scientists: 1990's style. Investigating: Australian Primary and Junior Science Journal, 12,4-10.

Bricheno, P., Johnston, J., \& Sears, J. (2000). Children's attitudes to science: beyond the men in white coats. In J. Sears \& P. Sorensen (Eds.), Issues in science teaching (pp. 143-154). London and New York: Routledge Falmer.

Britner, S. L. (2008). Motivation in high school science students: a comparison of gender differences in life, physical, and earth science classes. Journal of Research in Science Teaching, 45, 955-970.

Britner, S. L., \& Pajares, F. (2006). Sources of science self-efficacy beliefs of middle school students. Journal of Research in Science Teaching, 43, 485-499.

Buck, G., Cook, K., Quigley, C., Eastwood, J., \& Lucas, Y. (2009). Profiles of urban, Iow SES, African American girls' attitudes toward science. Journal of Mixed Methods Research, 3, 386-410.
Calabrese Barton, A., Tan, E., \& Rivet, A. (2008). Creating hybrid spaces for engaging school science among urban middle school girls. American Educational Research Journal, 45, 68-103.

Cavas, B., Cavas, P., Tekkaya, C., Cakiroglu, J., \& Kesercioglu, T. (2009). Turkish students' views on environmental challenges with respect to gender: an analysis of ROSE data. Science Education International, 20(1-2), 69-78.

Ceci, S. J., Ginther, D. K., Kahn, S., \& Williams, W. M. (2014). Women in academic science: a changing landscape. Psychological Science in the Public Interest, 15(3), 75-141.

Chang, S., Yeung, Y., \& Cheng, M. (2009). Ninth graders' learning interests, life experiencesand attitudes towards science \& technology. Journal of Science Education and Technology, 18, 447-457.

Chen, J., Tutwiler, S., Metcalf, S., Kamarainen, A., Grotzer, T., \& Dede, C. (2016). A multi-user virtual environment to support students' self-efficacy and interest in science: a latent growth model analysis. Learning and Instruction, $41,11-22$.

Christensen, R., Knezek, G., \& Tyler-Wood, T. (2014). Student perceptions of science, technology, engineering and mathematics (STEM) content and careers. Computers in human behavior, 34, 173-186.

Christidou, V. (2006). Greek students' science-related interests and experiences: gender differences and correlations. International Journal of Science Education, 28, 1181-1199.

Cleaves, A. (2005). The formation of science choices in secondary school. International Journal of Science Education, 27(4), 471-486.

Clewell, B. C., \& Campbell, P. B. (2002). Taking stock: where we've been, where we are, where we're going. Journal of Women and Minorities in Science and Engineering, 8(3\&4), 255-284.

Colley, A., Comber, C., \& Hargreaves, D. (2003). School subject preference of students in single sex and co-educational secondary schools. Educational studies, 20, 379-386.

Comrey, A., \& Lee, H. (1992). A first course in factor analysis (2nd ed.). Hillsdale: Lawrence Erlbaum Associates.

Correl, S. (2004). Constraints into preferences: gender, status, and emerging career aspirations. American Sociological Review, 69(1), 93-113.

Craig, J., \& Ayres, D. (1988). Does primary science affect girls' and boys' interest in secondary science? School Science Review, 69, 417-426.

Creagh, C., \& Parlevliet, D. (2014). Enhancing student engagement in physics using inquiry oriented learning activities. International Journal of Innovation in Science and Mathematics Education, 22(1), 43-56.

Crisp, G., Nora, A., \& Taggart, A. (2009). Student characteristics, pre-college, college, and environmental factors as predictors of majoring in and earning a STEM degree: An analysis of students attending a Hispanic Serving Institution. American Educational Research Journal, 46(4), 924-942.

Dimopoulos, K., \& Smyrnaiou, Z. (2005). Factors related to students' interest in science learning. In D. Koliopoulos \& A. Vavouraki (Eds.), Science education at cross roads: meeting the challenges of the 21st century (pp. 135-142). Athens: Association for Science Education.

Driver, R., Leach, J., Millar, R., \& Scott, P. (1996). Young people's images of science. Buckingham: Open University Press.

Ebenezer, J. V., \& Connor, S. (1998). Learning to teach science: a model for the 21st century. New Jersey: Prentice-Hall.

Fabrigar, L., Wegener, D., MacCallum, R., \& Strahan, E. (1999). Evaluating the use of exploratory factor analysis in psychological research. Psychological Methods, 4(3), 272-299.

Faitar, G., \& Faitar, S. (2013). Teachers' influence on students' science career choices. American International Journal of Social Science, 2(5), 10-16.

Field, A. (2005). Discovering statistics using SPSS (2nd ed.). London: Sage Publications Ltd.

Fornell, C., \& Larcker, D. F. (1981). Evaluating structural equation models with unobservable variables and measurement error. Journal of Marketing Research, 18, 39-50.

Gafoor, K., \& Smitha, N. (2012). Out-of-school experience categories influencing interest in science of upper primary students by gender and locale: exploration on an Indian sample. Science Education International, 23(3), 191-204.

Gardner, P. L. (1975). Attitudes to science. Studies in Science Education, 2, 1-41.

Gardner, P. L., \& Tamir, P. (1989). Interest in biology. Part 1: a multi-dimensional construct. Journal of Research in Science Teaching, 26(5), 409-423.

Gough, N. (2002). What's in a game? The Australian children's television foundation. Accessed from: http://www.actf.com.au/learning_centre_new/Lesson_ldeas/ CrashZone/htm/whats_ina_game.htm. Accessed Mar 2015. 
Guadagnoli, E., \& Velicer, W. (1988). Relation of sample size to the stability of component patterns. Psychological Bulletin, 103, 265-275.

Hair, J. F., J., Anderson, R. E., Tatham, R. L., \& Black, W. C. (1998). Multivariate data analysis (5th ed.). Upper Saddle River: Prentice Hall.

Hair, F. J., Black, W. C., Babin, B. J., \& Anderson, R. E. (2009). Multivariate data analysis: a global perspective (7th ed.). New York: Macmillan.

Hatzinikita, V. (2007). Images of the scientist held by educators in Greece. International Journal of Learning, 14, 145-154.

Haussler, P. (1987). Measuring students' interest in physics: design and results of a cross-sectional study in the Federal Republic of Germany. International Journal of Science Education, 9, 79-92.

Hebel, F., Montpied, P., \& Fontanieu, V. (2014). What can influence students' environmental attitudes? Results from a study of 15-year-old students in France. International Journal of Environmental \& Science Education, 9, 329-345.

Henriksen, D. \& Mishra, P. (2013). Learning from creative teachers. Educational Leadership. 70(5). Retrieved from http://www.ascd.org/ publications/educationalleadership/feb13/vol70/num05/Learning-fromCreative-Teachers.aspx. Accessed Jan 2016.

Hill, C., Corbett, C., \& St. Rose, A. (2010). Why so few? Women in science technology, engineering, and mathematics. Washington, DC: American Association of University Women.

Hossain, M., \& Robinson, M. (2012). How to motivate us students to pursue STEM (science, technology, engineering and mathematics) careers. US-China Education Review, 4(A), 442-451.

Hossler, D., \& Stage, F. K. (1992). Family and high school experience influences on the post-secondary educational plans of ninth-grade students. American Educational Research Journal, 29(2), 425-451.

Huang, H. P., \& Yore, L. D. (2003). A comparative study of Canadian and Taiwanese grade 5 children's environmental behaviors, attitudes, concerns, emotional dispositions, and knowledge. International Journal of Science and Mathematics Education, 1(3), 419-448.

Hyde, J. S., \& Jaffee, S. (1998). New perspectives on gender differences in mathematics: perspectives from social and feminist psychology. Educational Researcher, 27, 14-16.

Iqbal, H., Bibi, F., \& lqbal, N. (2015). Exploring factors affecting grade VIII students' attainment in science: options for reforms. American Journal of Educational Science, 1(4), 210-217.

Jenkins, E. W. (2006). Student opinion in England about science and technology. Research in Science \& Technological Education, 24(1), 59-68.

Jenkins, E. W., \& Nelson, N. W. (2005). Important but not for me: students' attitudes towards secondary school science in England. Research in Science and Technological Education, 23(1), 41-57.

Jenkins, E. W., Pell, R.G. 2006. The relevance of science education project (ROSE) in England: a summary of findings. Centre for Studies in Science and Mathematics Education, University of Leeds. http://roseproject.no/network/ countries/uk-england/rosereport-eng.pdf.

Jones, A., \& Kirk, C. (1990). Introducing technological applications into the physics classroom. Help or hindrance to learning? International Journal of Science Education, 12(5), 481-490.

Jones, G., Howe, A., \& Rua, M. (2000). Gender differences in students' experiences, interests, and attitudes towards science and scientists. Science Education, 84, 180-192.

Jöreskog, K. G., \& Sörbom, D. (1993). LISREL 8: structural equation modeling with the SIMPLIS command language. Chicago: Scientific Software International.

Keeves, J., \& Kotte, D. (1992). Disparities between the sexes in science education: 1970-84. In J. Keeves (Ed.), The IEA study of science III. New York: Pergamon.

Kelly, J. (2000). Rethinking the science methods course: A case for content, pedagogy, and informal science education. International Journal of Science Education, 22, 755-777.

Kier, M., Blanchard, M., Osborne, J. \& Albert, J. (2016). The Development of the STEM career interest survey (STEM-CIS). Research in Science Education, doi:10.1007/s11165-013-9389-3.

Kim, J., \& Song, J. (2010). A confirmatory structural equation model of achievement estimated by dichotomous attitudes, interest, and conceptual understanding. Eurasia Journal of Mathematics, Science \& Technology Education, 6(4), 271-285.

Kline, R. B. (2010). Principles and practice of structural equation modeling (3rd ed.) New York: Guilford Press.

Kniveton, B. H. (2004). The influences and motivations on which students base their choice of career. Research in Education, 72, 47-59.

Koch, J. (1990). The science autobiography. Science and Children, 28, 42-43.
Koosimile, A. T. (2004). Out-of-school experiences in science classes: problems, issues and challenges in Botswana. International Journal of Science Education, 26(4), 483-496.

Krapp, A. (2005). Basic needs and the development of interest and intrinsic motivational orientations. Learning and Instruction, 12, 383-409.

Kroß, A. (1998). Development and evaluation of a concept for instruction on computer-supported flowing water analysis in biology. In H. Bayrhuber \& F. Brinkman (Eds.), What - Why - How? Research in Didaktik of Biology (Proceedings of the 1st Conference of European Researchers in Didaktik of Biology (ERIDOB), pp. 85-92). Kiel: IPNMaterialen.

Lavonen, J., Byman, R., Uitto, A., Juuti, K., \& Meisalo, V. (2008a). Students' interest and experiences in physics and chemistry related themes: reflections based on a ROSE-survey in Finland. Themes in Science and Technology Education, 1(1), 7-36

Lavonen, J., Gedrovics, J., Byman, R., Meisalo, V., Juuti, K. \& Uitto, A. (2008b). Students' motivational orientations and career choice in science and technology: a survey in Finland and Latvia. Journal of Baltic Science Education, 7(2) 86-103

Leech, N. L., Barrett, K. C., \& Morgan, G. A. (2005). SPSS for intermediate statistics: use and interpretation (2nd ed.). Mahwah: Lawrence Erlbaum Associates.

Lent, R. W., Brown, S. D., \& Hackett, G. (1994). Toward a unifying social cognitive theory of career and academic interest, choice, and performance. Journal of Vocational Behavior, 45, 79-122.

Lewis, B. F., \& Collins, A. (2001). Interpretive investigation of the science-related career decisions of three African-American college students. Journal of Research in Science Teaching, 38(5), 599-621.

Lord, T. (1997). A comparison between traditional and constructivist teaching in college biology. Innovative Higher Education, 21(3), 1127-1147.

MacCallum, R., Widaman, K., Zhang, S., \& Hong, S. (1999). Sample size in factor analysis. Psychological Methods, 4, 84-89.

Manski, C., \& Wise, D. (1983). College Choice in America. Cambridge: Harvard University Press.

Melnick, C. R. (1991). Learning the in and out-of school curriculum. International Journal of Educational Research, 15(2), 201-214.

Millar, R., \& Osborne, J. F. (Eds.). (1998). Beyond 2000: science education for the future. London: King's College London.

Miller, J. \& Kimmel, L. (2010). Pathways to a STEMM career. Report from Michigan State University. Accessed from http://news.msu.edu/media/documents/ 2010/02/79874644-d2cb-4def-a17f-e67cc27b929d.pdf.

Miller, J., \& Solberg, V. (2012). The composition of the STEMM workforce: rationale for differentiating STEMM professional and STEMM support careers. Peabody Journal of Education, 87, 6-15.

Miller, P., Blessing, J. S., \& Schwartz, S. (2006). Gender differences in high-school students' views about science. International Journal of Science Education, 28, 363-381.

Murray, I. \& Reiss, M. (2005). The student review of the science curriculum. School Science Review, 87(318), 83-93.

Muskin, J. A. (1997). Becoming an independent entrepreneur in the informal sector of northern Cote d'Ivoire: what role can primary schooling play? International Journal of Educational Development, 17, 265-283.

National Research Council (NRC). 1996. National science education standards. National Committee on Science Education Standards and Assessment. Center for Science, Mathematics, and Engineering Education. Washington, DC: National.

OECD. (2006). Assessing scientific, reading and mathematical literacy: a framework for PISA 2006. Paris: OECD.

Ogunkola, B. (2011). Science teachers' and students' perceived difficult topics in the integrated science curriculum of lower secondary schools in Barbados. World Journal of Education, 1(2), 17-29.

Olasimbo, O., \& Rotimi, C. (2012). Attitudes of students towards the study of physics in College of Education Ikere Ekiti, Ekiti State, Nigeria. American International Journal of Contemporary Research, 2(12), 86-89.

Ormerod, M., \& Duckworth, D. (1975). Students' attitudes to science, Slough, National Foundation for Educational Research. Berkshire: United Kingdom.

Osborne, J., \& Collins, S. (2000). Students' and parents' views of the school science curriculum. London: King's College London.

Osborne, J., \& Collins, S. (2001). Students' views of the role and value of the science curriculum: a focus group study. International Journal of Science Education, 23(5), 441-467.

Osborne, J., Simon, S., \& Collins, S. (2003). Attitudes towards science: a review of the literature and its implications. International Journal of Science Education, $25,1049-1079$ 
Oversby, J. (2005). What does research say about attitudes towards science education? Education in Science, 215, 22-23.

Owen, S., Dickson, D., Stanisstreet, M., \& Boyes, E. (2008). Teaching physics: students' attitudes towards different learning activities. Research in Science and Technological Education, 26(2), 113-128.

Packard, B. W.-L., \& Nguyen, D. (2003). Science career-related possible selves of adolescent girls: a longitudinal study. Journal of Career Development, 29(4), 251-263.

Payne, P. (1998). Children's conceptions of nature. Australian Journal of Environmental Education, 14, 19-26.

Quita, I. N. (2003). What is a scientist? Perspectives of teachers of color. Multicultural Education, 2003, 29-31.

Reid, N. (2003). Gender and physics. International Journal of Science Education, 25(4), 509-536.

Rennie, L. J. (2005). Science awareness and scientific literacy. Teaching Science - the Journal of the Australian Science Teachers Association, 51(1), 5.

Roberts, G. (2002). SET for success: the supply of people with science, technology, engineering and mathematics skills: the report of Sir Gareth Roberts' review. London: HM Treasury.

Ryder, J. (2002). School science education for citizenship: strategies for teaching about the epistemology of science. Journal of Curriculum Studies, 34, 637-658.

Sadler, P. M., Sonnert, G., Hazari, Z., \& Tai, R. (2012). Stability and volatility of STEM career interest in high school: a gender study. Science Education, 96(3), 411-427.

Said, Z., Summers, R., Abd-El-Khalick, F., \& Wang, S. (2016). Attitudes toward science among grades 3 through 12 Arab students in Qatar: findings from a cross-sectional national study. International Journal of Science Education. 12(8), 2253-2265.

Samara, F. (2015). Factors influencing students' choice of elective science courses: a case study from the American University of Sharjah. Open Journal of Social Sciences, 3, 93-99.

Sarjou, A., Soltani, A., Afsaneh, K., \& Mahmoudi, S. (2012). A study of Iranian students' attitude towards science and technology, school science and environment, based on the ROSE project. Journal of Studies in Education, 2(1), 90-103. doi:10.5296/jse.v2i1.1438.

Scherz, Z., \& Oren, M. (2006). How to change students' images of science and technology. Science Education, 90(6), 965-985. doi:10.1002/sce.20159.

Schibeci, R., \& Lee, L. (2003). Portrayals of science and scientists, and "science for citizenship". Research in Science and Technological Education, 21, 177-192.

Schreiner, C., \& Sjøberg, S. (2004). Sowing the seeds of ROSE. Background, rationale, questionnaire development and data collection for ROSE (relevance of science education) - a comparative study of students' views of science and science education. Acta Didactica 4. Oslo: University of Oslo Department of Teacher Education and School Development.

Schumacker, R. E., \& Lomax, R. G. (2010). A beginner's guide to structural equation modeling. New York: Routledge.

Schwedes, H. (2005). Gender bias in science and science education. Retrieved from: http://www.physik.unibremen.de/physics.education/schwedes/text/bellater.htm. Accessed Jan 2016.

Scott, A. B., \& Mallinckrodt, B. (2005). Parental emotional support, science self-efficacy, and choice of science major in undergraduate women. The Career Development Quarterly, 53(3), 263-273.

Semela, T. (2010). Who is joining physics and why? Factors influencing the choice of physics among Ethiopian university students. International Journal of Environmental and Science Education, 5, 319-340.

Siegel, M. A., \& Ranney, M. A. (2003). Developing the changes in attitude about the relevance of science (CARS) questionnaire and assessing two high school science classes. Journal of Research in Science Teaching, 40, 757-775.

Sjøberg, S. (2000a). Interesting all children in 'science for all'. In R. Millar, J. Leach and J. Osborne (Eds.), Improving Science Education: The Contribution of Research (pp. 1-59). Buckingham, UK: Open University Press.

Sjøberg, S. (2000b). Science and scientists: the SAS-study. Cross-cultural evidence and perspective on students interests, experiences and perceptionsbackground, development and selected results. Acta Didactica. (1/2000). Dept. of Teacher Education and School Development. University of Oslo

Sjøberg, S. (2002a). Science and technology education in Europe: current challenges and possible solutions. Technology, and Environmental Education Newsletter, 27, 1-5.

Sjøberg, S. (2002b). Science for the children? A report from the science and scientists project. Acta Didactica. (1/2002) Dept. of Teacher Education and School Development. University of Oslo
Sjøberg, S. (2002c). Science and technology education in Europe: current challenges and possible solutions. Connect UNESCO (E.W. Jenkins ed), 27(3-4), 1-5.

Sjøberg, S., \& Schreiner, C. (2010). The ROSE project. An overview and key findings, Accessed from http://roseproject.no/network/countries/norway/eng/ nor-SjobergSchreiner-overview-2010.pdf. Accessed Mar 2015.

Spector, P. (1992). Summated rating scale construction: an introduction. Newbury Park: Sage.

Stagg, P., Laird, R. \& Taylor, P. (2003). Widening participation in the physical sciences: an investigation into factors influencing the uptake of physics and chemistry. Final report. Coventry: The University of Warwick, Centre for Education and Industry.

Stevens, J. (1992). Applied multivariate statistics for the social sciences (2nd ed.). Hillsdale: Erlbaum.

Strike, K. A., \& Posner, G. J. (1992). A revisionist theory of conceptual change. In R. Duschl \& R. Hamilton (Eds.), Philosophy of science, cognitive psychology, and educational theory and practice (pp. 147-176). Albany: SUNY Press.

Szagun, G., \& Pavlov, V. (1995). Environmental awareness. Youth \& Society, $27,93-112$.

Tabachnick, B., \& Fidell, L. (2007). Using multivariate statistics (5th Ed.). Boston: Pearson Education Inc.

Tan, E., \& Calabrese Barton, A. (2008a). From peripheral to central, the story of Melanie's metamorphosis in an urban middle school science class. Science Education, 92, 567-590.

Tan, E., \& Calabrese Barton, A. (2008b). Unpacking science for all through the lens of identities-in practice: the stories of Amelia and Ginny. Cultural Studies of Science Education, 3, 43-71.

Tisdal, J. F., Dunbar, C. E., Lozier, J., Goodman, S. (2005). Gene therapy for hematologic disorders, HIV infection and cancer, Wintrobe's Clinical Hematology. In Lee, Foerster, Greer, Lukens, Rodgers, and Paraskevas, 11th edition; (pp. 911-943). Williams and Wilkens.

Trumper, R. (2006a). Factors affecting junior high school students' interest in physics. Journal of Science Education and Technology, 15(1), 47-58. doi:10.1007/s10956-006-0355-6.

Trumper, R. (2006b). Factors affecting junior high school students' interest in biology. Science Education International, 17(1), 31-48.

Tunnicliffe, S. D., \& Reiss, M. J. (2000). Building a model of the environment: how do children see plants? Journal of Biological Education, 34(4), 172-177.

Turkmen, H. (2008). Turkish primary students' perceptions about scientist and what factors affecting the image of the scientists. Eurasian Journal of Mathematics, Science \& Technology Education, 4, 55-61.

Tuttle, R. (1981). Evolution of hominid bipedalism and prehensile capabilities. Philosophical Transactions of the Royal Society of London, Series B, 292, 89-94.

Tyler-Wood, T., Knezek, G., \& Christensen, R. (2010). Jl. of Technology and Teacher Education, 18(2), 341-363.

U.S. Department of Commerce. (2011). STEM: Good Jobs Now and for the Future. Economics and Statistics Administration. Accessed from http://www.esa.doc. gov/sites/default/files/stemfinalyjuly14_1.pdf. Accessed Sept 2015.

Uitto, A. J., Juuti, K., Lavonen, J., \& Meisalo, V. (2006). Students' interests in biology and their out-of-school experiences. Journal of Biological Education, 40(3), 124-129.

Unlu, Z., Dokme, T., \& Unlu, V. (2016). Adaptation of the science, technology, engineering, and mathematics career interest survey (STEM-CIS) into Turkish. Eurasian Journal of Educational Research, 63, 21-36.

VanLeuvan, P. (2004). Young women's science/mathematics career goals from seventh grade to high school graduation. The Journal of Educational Research, 97(5), 248-267.

Velicer, W., \& Fava, J. L. (1998). Effects of variable and subject sampling on factor pattern recovery. Psychological Methods, 3, 231-251.

Wang, X. (2013). Why students choose STEM majors: motivation, high school learning, and postsecondary context of support. American Educational Research Journal, 50(5), 1081-1121.

Wang, J., \& Staver, J. R. (2001). Examining relationships between factors of science education and student career aspiration. The Journal of Educational Research, 94(5), 312-319.

Yager, R. E., \& Yager, S. O. (1985). Changes in perceptions of science for third, seventh and eleventh grade students. Journal of Research in Science Teaching, 22(4), 347-358.

Yan, C., Jing, C., \& Yu, Y. (2015). A survey study of employment intention and related factors in medical college students. Biomedical Research, 26(3), 493-496.

Yong, A., \& Pearce, S. (2003). A beginner's guide to factor analysis: focusing on exploratory factor analysis. Tutorials in Quantitative Methods for Psychology, 9(2), 79-94. 